Pamiętnik Literacki 2018, 2, s. 139-162

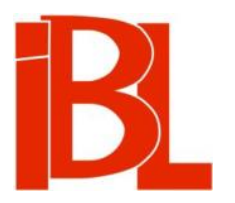

\title{
Komparatystyka Mariana Szyjkowskiego
}

\author{
Krystyna Kardyni-Pelikánová
}


Pamiętnik Literacki CIX, 2018, z. 2, PL ISSN 0031-0514

DOI: $10.18318 / \mathrm{pl} .2018 .2 .7$

KRYSTYNA KARDYNI-PELIKÁNOVÁ Masarykova univerzita, Brno

\section{KOMPARATYSTYKA MARIANA SZYJKOWSKIEGO}

Profesora Mariana Szyjkowskiego (1883-1952) żegnał wspomnieniem pośmiertnym Tadeusz Stanisław Grabowski, wymieniając wiele jego tytułów uprawniających do sławy lub przynajmniej do trwałej pamięci:

21 września zmarł [...] Marian Szyjkowski, profesor języka polskiego i literatury na Wydziale Filologicznym Uniwersytetu Karola, były profesor Uniwersytetu Jagiellońskiego w Krakowie i kustosz Biblioteki Jagiellońskiej, członek zwyczajny Slovanskiego ústavu, nadzwyczajny członek Královské České Společnosti Nauk, członek Polskiej Akademii Umiejętności w Krakowie, członek Towarzystwa Naukowego Warszawskiego ${ }^{1}$.

Cytował też tekst zawiadomienia-nekrologu nadesłanego $\mathrm{z}$ uniwersytetu praskiego do Polski:

Zmarły przez lat 30 działał w Pradze i wszystkie swe siły poświęcił idei zbliżenia czechosłowackiego i polskiego ludu. Swym bogatym wkładem naukowym stworzył podstawy dla praskiej polonistyki. Nauka słowiańska traci w nim jednego z czołowych przedstawicieli ${ }^{2}$.

Szczególnie dużo pięknych słów Grabowski poświęcił Szyjkowskiemu w swej obszernej pracy Dorobek literacko-naukowy Mariana Szyjkowskiego. (Polskie czterdziestolecie: 1912-1952 i czeskie trzydziestolecie: 1922-1952)3. Przypomniał w niej, jak wielu znakomitych polskich literaturoznawców oddawało hołd jego rozległej wiedzy, podziwiało jego piękną polszczyznę, choć i polemizowało z nim czasem (Bruchnalski, Brückner, Chlebowski, Chmielowski, Chrzanowski, Feldman, Górscy, Grabowski, Gubrynowicz, Hann, Jabłonowski, Kallenbach, Kleiner, Kridl, Matkowski, Porębowicz, Wierczyński i inni).

Jak to się więc stało, że na łożu śmierci Szyjkowski skarżył się w jednym z ostatnich swoich listów pisanych do Grabowskiego, iż kilka jego późniejszych prac „snem wiecznym spoczywa" w archiwach ${ }^{4}$, i ta gorzka ironia umierającego była aktualna niemal do chwili bieżacej ${ }^{5}$ ?

1 T. S. G r a b o w s ki, Wspomnienie pośmiertne: Marian Szyjkowski (1883-1952). „Rocznik Towarzystwa Naukowego Warszawskiego" 45 (1952), s. 114.

2 Ibidem.

3 T. S. G r a b ow s k i, Dorobek literacko-naukowy Mariana Szyjkowskiego. (Polskie czterdziestolecie: 1912-1952 i czeskie trzydziestolecie: 1922-1952). W zb.: Franku Wollmanovi k sedmdesátinám. Red. A. Zá vo d s ký. Praha 1958. Artykuł ten, mówiąc słowami Grabowskiego, stał się najobszerniejszym chyba wspomnieniem pośmiertnym o Szyjkowskim.

4 M. Szyjkow s ki, list do T. S. Grabowskiego, z 21 VI 1952. Bibl. Jagiellońska. Dział Rękopisów, sygn. Przyb. 463/77. Zob. Aneks 1.

5 Milczenie o profesorze zdecydowanie przerwały dopiero obchody 90-lecia praskiej i brneńskiej 
Kiedy Szyjkowski w 1923 r. przystał na zaproszenie strony czeskiej i obją w Uniwersytecie Karola w Pradze kierownictwo pierwszej - nie tylko w Europie, ale i na świecie - katedry polonistyki zagranicznej, miał już poza sobą wiele poważnych prac z zakresu komparatystyki genetycznej, reprezentującej pozytywistyczny etap jej rozwoju i objaśniającej zjawiska literackie metoda przyczynowo-skutkową, oraz obszerne rozważania na temat typologii dramatu polskiego, również zachowujące spojrzenie genetyczno-porównawcze, nie mówiąc o obfitej publicystyce czy tekstach przeznaczonych do użytku szkolnego. O swoich poczatkowych pracach komparatystycznych wspomina w dotąd nie opublikowanym pamiętniku Lemiesz i lutnia nie bez wyraźnego poczucia dumy:

chciałem nareszcie poznać osobiście francuskich komparatystów Baldenspergera, a zwłaszcza Paul Van Tieghema - „zwłaszcza” dlatego, że z Van Tieghemem utrzymywałem korespondencję, nawiązaną jeszcze w czasie krakowskim. Okazało się mianowicie, że ja w Krakowie, a on w Paryżu opracowujemy identyczne tematy, nic o tym nawzajem nie wiedzac - przy czym ja moge przytoczyć na swoje usprawiedliwienie, że wszędzie moje studia na temat preromantyzmu w Polsce są daty wcześniejszej aniżeli prace Van Tieghema na temat preromantyzmu w Europie. Są to i w tytule niemal tożsame studia nad „youngizmem”, „osjanizmem”, ,gessneryzmem”, które ogłosiłem w rozprawach PAU w latach 1912-1917, nie mając szczęścia wydać je razem, jak Van Tieghem, którego Le Préromantisme, obejmujący trzy poprzednio ogłoszone prace, wydał drukiem F. Rieder w Paryżu w 1924 [roku]. O moich studiach dowiedział się Van Tieghem ze sprawozdań Akademii, trochę późno ${ }^{6}$.

Objęcie Katedry Literatury i Języka Polskiego w uniwersytecie praskim nakładało na polskiego profesora obowiązek obmyślenia i ustalenia programu dydaktycznego ${ }^{7}$, z czego wywiazał się on wyśmienicie, o czym świadczy szereg jego znanych, a nawet wybitnych czeskich uczniów, z Karelem Krejčím na czele. Jednocześnie wyjazd do Czechosłowacji wymagał zastanowienia się nad tematyką dalszej własnej

polonistyki oraz publikacje R. B a ro na, będące wstępem do przygotowywanej przez niego w Instytucie Historii Czeskiej Akademii Nauk biografii Szyjkowskiego, m.in.: Prof. Marian Szyjkowski a česko-polská vzájemnost I (1921-1939). „Sborník prací Pedagogické fakulty Masarykovy univerzity, řada společenských věd” 27 (2013), nr 1; Spetniona misja. Prof. Marian Szyjkowski a „wzajemność" polsko-czeska. W zb.: Na obrzeżach polityki. Red. M. Ko s ma n. Cz. 9. Poznań 2013; Profesor Marian Szyjkowski oczami historyka. Z rozważań nad przyszłą biografia twórcy czeskiej polonistyki uniwersyteckiej. W: M. B e n e š o vá [i in.], Proměny polonistiky. Tradice a výzvy polonistických studii. Praha 2014; Przed podjęciem misji życiowej. Z lwowskiej drukarni w świat literatury. Droga Mariana Szyjkowskiego do objęcia Katedry Języka i Literatury Polskiej Uniwersytetu Karola w Pradze. „Historia Slavorum Occidentis” 7 (2015), nr 1; Zaproszenie z Pragi. Marian Szyjkowski obejmuje Katedre Języka i Literatury Polskiej na Uniwersytecie. W zb.: Obszary i przestrzenie edukacji: meandry, konteksty, dylematy. Księga jubileuszowa dedykowana profesorowi Zenonowi Jasińskiemu $w$ 70. rocznice urodzin. Red. E. Ka r c - Ta r a n ow i cz. Opole 2016; Od stereotypów narodowych do misji polsko-czeskiego zbliżenia. Fragment przebytej drogi Mariana Szyjkowskiego. W zb.: Na obrzeżach polityki, cz. 11 (2017). Zob. też R. B a r o n, E. Głę b i ck a, Szyjkowski Marian. W: Polski słownik biograficzny. T. 50, z. 1: Szyjkowski Jan - Szymański Edward. Warszawa-Kraków 2014.

$6 \quad$ M. Szyjkowski, Lemiesz i lutnia. T. 1: Wspomnienia. Muzeum Literatury im. Adama Mickiewicza w Warszawie, mpis nr 1382, s. 241.

7 Grabows ki (Dorobek literacko-naukowy Mariana Szyjkowskiego, s. 351) informuje, iż omówił jego program dydaktyczny w pracy „przeznaczonej dla Rocznika Towarzystwa Naukowego Warszawskiego 1952". Niestety, nie udało mi się do niej dotrzeć, być może dlatego, że w okresie stalinowskim TNW zostało, w r. 1951, zlikwidowane (reaktywowano je dopiero w 1981 roku). 
pracy w zakresie badań porównawczych. Szyjkowski zdecydował się na - naturalne w jego sytuacji - śledzenie kontaktów i powiązań pomiędzy literaturą polską a czeską.

Praca naukowa Szyjkowskiego rozwijała się do owej chwili w kilku kierunkach. Najważniejszym jednakże wątkiem w jego życiu naukowym stawał się coraz wyraźniej wattek komparatystyczny, a dokładniej: w pierwszym, „polskim” okresie badań - Polska jako obszar przyjmowania obcych, zachodnich inspiracji w preromantycznej fazie dziejów rodzimej literatury; w okresie zaś drugim, związanym z pobytem w Czechach - Polska jako obszar oddziałujący własnymi osiagnięciami na polu literackim na recypująca je literaturę czeską. W obu przypadkach uczony starał się uchwycić i opisać przyczyny oraz skutki literackie (i nie tylko) owych inspiracji, a także czas, uwarunkowania i sposoby realizacji polskich, potem zaś czeskich zachowań adaptacyjnych. W przypadku drugim, jak sam przyznawał, pewnym kierunkowskazem stał się dla niego również artykuł Jana Máchala ${ }^{8}$ (ucznia m.in. Aleksandra Brücknera), wykładającego w uniwersytecie praskim dzieje literatur słowiańskich, poświęcony znaczeniu twórczości Mickiewicza dla literatury czeskiej doby odrodzenia narodowego, które to odrodzenie, dodajmy - po latach wojen religijnych, klęsk, emigracji lub wynarodowienia i wreszcie po zaniku dawnych elit czeskich - miało miejsce w pierwszej połowie XIX wieku. Wówczas to czescy „budziciele" poczucia tożsamości narodowej, wykorzystując do swych celów m.in. literature $^{9}$, stanęli przed niesłychanie trudnym zadaniem. Oddajmy głos Szyjkowskiemu:

Dokonali jedynego $\mathrm{w}$ swoim rodzaju cudu w historii: obudzili naród $\mathrm{z}$ letargu, a uczynili to za pomocą nauki, która w tym wypadku działała „ku pokrzepieniu serc“ - i zwyciężyła, choć musiała nawiązywać stargane więzy z przeszłością, choć musiała wytworzyć słownik, ustalić ortografię, wprowadzić alfabet łaciński na miejsce szwabachy, zrekonstruować budowę gramatyczną, dać prawidła prozodii i metrum. W tej niezmiernie trudnej pracy szukano pomocy u Słowian, zwłaszcza najbliższych geograficznie, językowo, religijnie i kulturalnie. [...] Polska stoi u kolebki czeskiego odrodzenia w dziedzinie literatury pięknej, głównie zaś na polu form wierszowanych $[\ldots]^{10}$.

Chcąc pokusić się o pełne odtworzenie modelu komparatystyki polskiego badacza w całym przebiegu jego życia naukowego, i to zarówno na tle literaturoznawstwa polskiego oraz kultury polskiej, jak też potem - literackiego i kulturalnego środowiska czeskiego, stajemy wobec pewnych trudności. Nie znamy biblioteki Szyjkowskiego, jego lektur, kwerend w Ossolineum, w Jagiellonce, a co dopiero w Genewie, dokąd badacz na czas pewien wyjechał. Wiemy, że wyniósł ze szkół znajomość kilku języków, można przypuszczać, że ówczesną europejską (szczególnie francuską i niemiecką) literaturę naukową poznawał w oryginale. Jedną z głów-

9 Jeszcze niedawno czeski filozof, długoletni emigrant, współpracownik „Kultury” paryskiej Giedroycia twierdził w wykładzie dla senatu czeskiego, że artyści słowa daja jakiejś zbiorowości etnicznej Idee i Słowo, czyniąc z niej świadomy Naród - zob. E. K o há k, Co dluží básník národu? „Literární noviny" 2010, nr z 2 III. Na stronie: http://literarky.cz/component/content/article/2095-co-dlui-basnik-narodu (data dostępu: 19 III 2018).

10 M. Szyj kow s ki, Polská účast v českém národním obrození. Cz. 1. Praha 1931, s. 4. Wobec braku pierwotnego tekstu polskiego (rękopisu) korzystam $z$ wydania czeskiego; cytowany fragment przeł. R. Ba ro n. W języku polskim ukazała się skrócona wersja: Polski udział $w$ czeskim odrodzeniu. (Próba rekapitulacji) (Poznań 1935), w której jednak tego fragmentu nie ma. 
nych ścieżek naszych dociekań pozostaje wszakże w zasadzie aparat naukowy (przypisy, odsyłacze), jaki w swych pracach Szyjkowski stosował, oraz jego wypowiedzi, zwłaszcza te rozsiane w streszczeniach drugiej z kolei, nigdy nie wydanej, choć przetłumaczonej na czeski trylogii ${ }^{11}$, poświęconej recepcji i roli w czeskiej kulturze trzech największych twórców polskiego romantyzmu. Tam bowiem można by poszukiwać wyjaśnień i akcentów polemicznych wobec stawianych jego metodzie zarzutów, które, choć często nawet otwarcie nie sformułowane, doprowadziły ostatecznie do przemilczania i wykluczenia uczonego jako śmiesznego nieco, bo niemodnego i lekceważonego „wpływologa”.

Nie wiemy np., czy i jaką rolę inspirującą w prowadzonej w Czechach pracy badawczej Szyjkowskiego odegrało 5-tomowe, wielokrotnie wznawiane dzieło Gottfrieda Gervinusa Geschichte der poetischen National-Literatur der Deutschen (18351842), którego autor chwalił niemiecką umiejętność korzystania z obcych informacji i bodźców oraz zdolność inspirowania i zapładniania innych literatur. Nie możemy więc wiedzieć z całą pewnością, czy stwierdzenie takiegoż oddziaływania od początku w. XIX literatury polskiej na czeską było dla badacza polskiego niespodziewanym odkryciem, czy rezultatem świadomych poszukiwań, inspirowanych po części właśnie Gervinusem.

Opierając się na cytowanej tu już wypowiedzi Szyjkowskiego o korespondencji z Van Tieghemem można jednak przypuszczać, że zrazu zawładnął jego wyobraźnią naukową przeważający czy wręcz panujący wtedy model francuski, pozytywistyczny, faktograficzno-genetyczny, bo we Francji rozwijał się on najwcześniej i najpełniej. Ale model w pewnym sensie przez Szyjkowskiego nieco przekształcony, co da się prześledzić już na przykładzie jego prac poświęconych literaturze polskiej.

Pojęcie wpływu zaistniało w literaturoznawstwie francuskim już w latach dwudziestych w. XIX, kiedy to zaczęto zastanawiać się właśnie nad oddziaływaniem XVIII-wiecznych pisarzy francuskich na literatury obce i na europejski sposób myślenia. Dziś niektórzy (zwłaszcza teoretycy postkolonializmu) moga przesadnie i niesłusznie dostrzegać w tym nastawienie inkorporacyjne czy wręcz tego rodzaju strategie. W dobie pierwszych publikacji Szyjkowskiego widziano to chyba nieco inaczej: jako nowoczesne rozprzestrzenianie się ocenianej pozytywnie fali „wysokiej” kultury łacińskiej czy szerzej - cywilizacji zachodniej, za której centrum uznano Francję, a której symbolem bywały zazwyczaj trzy wzgórza starożytne: Akropol (grecka filozofia i racjonalizm), Kapitol (rzymskie prawo i idea równości w jego obliczu oraz sprzeciw wobec przewagi silniejszego) i Golgota (chrześcijaństwo z idea wolności, braterstwa, odpowiedzialności).

Szyjkowski jednak już w swych wczesnych pracach komparatystycznych, dotyczacych literatury polskiej, podkreślał nie tyle siłe inspiracyjną kultury zachodnioeuropejskiej (ważną np. dla strony francuskiej), przyciaganie przez nią do siebie i przekazywanie literaturom obcym własnych wzorców, ile przygotowanie literatury rodzimej do przyjęcia ich oraz zdolność wchłaniania i rozwijania bodźców czerpanych $z$ literatur zachodnich przez literature polskiego oświecenia, a także -

11 Pierwsza trylogia to trzy tomy dzieła M. Szyjkow ks i e go Polská účast v českém národním obrozeni (Praha 1931-1946), na drugą składają się prace: Adam Mickiewicz v Čechách, Julius Słowacki $v$ české literatuře i Zikmund Krasiński $v$ české literatuře. 
i przede wszystkim - preromantyzmu ${ }^{12}$. Uwyraźniał w ten sposób jakby swobodne funkcjonowanie polskiej literatury czy wręcz kultury w zachodnim obszarze kulturowym oraz jej otwartość - jak byśmy dziś powiedzieli - na Innego, wcale nie traktowanego jako element obcy ani tym bardziej wrogi. Zasadnie można przypuszczać, że ten tryb myślenia towarzyszył Szyjkowskiemu i po wyjeździe do Czech.

Wczesną metodykę polskiego badacza, za której pomocą usiłował on objaśnić występowanie elementów obcego preromantyzmu w literaturze polskiej i inspirowanie się nimi przez naszych twórców, opisuje w 1915 r. Bronisław Gubrynowicz w swej rozprawce zatytułowanej Schiller $w$ Polsce. (Z powodu ksiażki dr. M. Szyjkowskiego):

Metoda autora polegała na zebraniu i ocenie materiału faktycznego, tj. wzmianek bio- i bibliograficznych, ustępów z korespondencji, tłumaczeń i przeróbek, krytyk i rozpraw, następnie zaś na rozpatrywaniu utworów oryginalnych i na oznaczeniu stopnia ich zależności od myśli obcej; rezultat studiów przedstawia się poważnie, choć krytyka poczyniła pewne zastrzeżenia i nie wszystkie wywody uznała za uzasadnione ${ }^{13}$.

Sam Szyjkowski początkowy etap swych prac komparatystycznych, odnoszących się do relacji między literaturą polską a literaturami zachodnimi, widział jednak znacząco inaczej i określał go w owym czasie - wydobywając już wtedy (w r. 1915!) szczególną, bo aktywną, rolę innonarodowego odbiorcy - w sposób następujący:

staraliśmy się dać pogląd na c ało ść zagadnienia, rozważanego jako zjawisko zbiorowe, w pierwszych okresach działania ściśle związane $z$ genezą romantycznego ruchu, a później jego część integralna, coraz trudniej z całości dająca się wyodrębnic ${ }^{14}$.

W tak przedstawionym rozumowaniu, zawartym we wczesnych pracach Szyjkowskiego, wciąż jeszcze dotyczących literatury polskiej, rysuja się więc wyraźnie dwa punkty odniesienia, dwa centra lojalności kulturowej tak w kulturze polskiej, jak i później w czeskiej: jedno centrum to centrum rodzime, centrum kontekstu lokalnego, ale obok tego zauważalnie zaznacza się centrum drugie, jakby wyprzedzające, przynoszące informacje o świecie zachodnim i swoiście recypowane przez pierwsze - to głównie centrum kultury zachodniej, łacińskiej, ze szczególnym uwzględnieniem kultury francuskiej, szwajcarskiej oraz niemieckiej (ale też angielskiej czy hiszpańskiej). Pod wpływem przyjmowanych - świadomie i wybiórczo - jego oddziaływań, kiedy niektórzy twórcy (bo nie zawsze czytelnicy) zdobyli już odpowiednie kompetencje międzykulturowe: artystyczne, estetyczne, ideowe (czyli według terminologii Szyjkowskiego osiagnęli wysoki stopien „europeizacji”, „modernizacji”, „emancypacji”), centrum czy środowisko rodzime dojrzewa i samo zaczyna wytwarzać wysokiej próby dzieła artystyczne w podobnym duchu, lecz wzbogacone o ele-

K. Krejčí już w 1930 r. wyraził pogląd, iż Szyjkowskiemu, badającemu w pierwszym okresie działalności naukowej początki romantyzmu w Polsce na tle europejskim, udało się pokazać, że była to pierwsza faza owego prądu w literaturze polskiej - zob. Kí [K. K r ej čí], Marian Szyjkowski. „Slovanský přehled” 1930, s. 565.

13 B. Gu bry now i z, Schiller w Polsce. (Z powodu ksiażki dr. M. Szyjkowskiego). Lwów 1916, s. 3. Odbitka z „Kwartalnika Historycznego” (1916, z. 1/2). Zob. też na stronie: www.polona.pl/ item/12799519/0/ (data dostępu: 19 III 2018).

14 M. Szyj kow s ki, Schiller w Polsce. Studium historyczno-porównawcze. Kraków 1915, s. VII-VIII. 
menty i pomysły czerpane $\mathrm{z}$ rodzimej kultury, jezzka czy sytuacji historycznej („palimpsesty narodowe”). I dopiero jako takie staje się w pełni twórczą częścią centrum zachodniego, a w literaturze przyjmującej zaczynają pojawiać się coraz bardziej wyrafinowane i często nastawione na dialog intertekstualne i intersemiotyczne nawiązania do kontekstu zachodnioeuropejskiego.

I ta myśl jest istotna.

W okresie międzywojennym, a nawet wcześniej (np. w przypadku Benedetta Crocego już w 1902 r.), przypuszczono atak na francuski genetyzm i zaczęto odchodzić od modelu migracjonistycznego, dostrzeżono bowiem jego ograniczenia, umożliwiające stawianie zarzutów właśnie „wpływologii”. W Polsce ową „wpływologię" o pozytywistycznych korzeniach ośmieszono w latach dwudziestych. Sam wywołujący wzgardliwe skojarzenia termin (a kpinę sugeruje już polsko-greckie złożenie), wymyślony i użyty po raz pierwszy przez Adama Grzymałę-Siedleckiego ${ }^{15}$ na oznaczenie gromadzenia bezpłodnych rzekomo zestawień, upowszechniał się szybko w związku z przełomem antypozytywistycznym w metodologii nauk humanistycznych, łatwo zaś dostępny w Internecie Słownikjęzyka polskiego PWN jeszcze w stosunkowo niedawnych wydaniach (2007) wyjaśniał jego znaczenie jako „nacechowane ironią uznawanie, iż czynnikami wywołującymi powstawanie dzieł oraz kształtującymi ich formę i styl sa głównie wpływy innych dzieł i innych twórców”.

Na tym tle powierzchownie odczytane (czy częściowo w ogóle nie czytane, bo nie wydane) prace Szyjkowskiego zaczęły uchodzić za przestarzałe i właściwie już zbyteczne - ot, ślepa, wpływologiczna uliczka polskiej komparatystyki (dodajmy: mimo iż sam praski profesor od prymitywnej wpływologii otwarcie się odżegnywał, krytykując np. z tego powodu książkę Juliusa Heidenreicha o wpływie Mickiewicza na literaturę czeską $\left.{ }^{16}\right)$. W centrum uwagi badaczy relacji bilateralnych stały bowiem już nie wzajemne związki, zależności, wpływy czy zapożyczenia literatur, lecz historyczne i społeczne uwarunkowania ich przyjęcia oraz wybór elementów przyjmowanych, jak też odkrywanie nowych znaczen, jakich elementy owe nabierały w innym otoczeniu językowym i kulturowym o odmiennych tradycjach; czyli stawiano nie tylko pytania: kto? co? kiedy? gdzie? przyswajał, lecz przede wszystkim: jak? i jakie były tego przyczyny oraz rezultaty? Zaczęto więc przechodzić od gromadzenia i ustalania faktów do bardziej szczegółowych studiów nad funkcjonowaniem sfer ludzkiej ekspresji w różniących się warunkach, a także do badania typologicznie zbieżnych zjawisk powstałych niezależnie od siebie przy analogicznych warunkach sprawczych. Karel Krejčí zwracał też uwagę na znaczenie europejskiej „atmosfery kulturowej”, która również wywoływać mogła powstawanie podobnych typologicznie zjawisk, niekoniecznie spowodowanych bezpośrednim oddziaływaniem na siebie konkretnych dzieł.

W metodyce stosowanej przez Szyjkowskiego można by się też dopatrzyć nie

15 W odpowiedzi na początkowe rozdziały broszury W. B o row e go $O$ wpływach $i$ zależnościach w literaturze (Kraków 1921) publikowane w 1920 r. w „Rzeczypospolitej”, pisane zaś z myślą obrony „ścisłości naukowej”, deprecjonowanej przez - jak ich Borowy nazwał - „subiektywistów” i impresjonistów" krytycznych, A. Grzymała-Siedlecki ogłosił w tejże gazecie w 1921 r. artykuły: Mania ścisłości (nr 19) oraz Wptywologia (nr 20) i Jeszcze o wptywologii (nr 21).

16 J. H e i d e n r e i c h, Vliv Mickiewiczův na českou literaturu předbřeznovou. Praha 1930. (Po drugiej wojnie światowej autor ten używał nazwiska D olan ský.) 
tylko pozytywistycznego genetyzmu (ten jest właściwy dla badań nad pierwszym stopniem recepcji w ujęciu uczonego), ale i płynącej z rozważań Wilhelma Diltheya hermeneutyki czy przynajmniej jej elementów. Bo czymże innym jest wyodrębniony przez autora Schillera $w$ Polsce etap drugi recepcji, jeśli nie przejściem od poznania zjawisk do ich rozumienia, wchłonięcia i oryginalnego już wykorzystania pewnych inspiracji, czyli przeżywania i tworzenia własnych, dojrzałych dzieł? Czymże są jego dzieje inspiracji polskich w czeskiej literaturze, jeśli nie Diltheyowskimi Geistesgeschichte - dziejami ducha, ściślej: dziejami ewolucji „ducha” czeskiego (czytaj: kultury czeskiej), przejawiającymi się w różnych postawach, dążeniach, poetyce, w działalności kulturalnej danego narodu? A można by dodać, używając dzisiejszego języka krytycznego: i dziejami przekraczania własnych barier recepcyjnych.

Szyjkowski nie był więc epigonem zamkniętej epoki. Jak staram się pokazać - zmiany zachodzace w badaniach komparatystycznych nie tylko dostrzegł, ale i był ich zapoznanym współtwórca, stosując je w swoim projekcie porównawczym, jaki wyłania się $\mathrm{z}$ jego pierwszej, wydanej w tłumaczeniu czeskim trylogii o polskim udziale w czeskim odrodzeniu narodowym. Świetnie to wyraził Slavomír Wollman, slawista i komparatysta, syn i kontynuator prac Franka Wollmana, stwierdzając:

Systematyczne badania związków na polsko-czeskim odcinku otworzył Marian Szyjkowski, który pod względem metodyki i tematyki zbliżał się do szkoły czeskiej ${ }^{17}$ już swymi pracami przed przybyciem do Pragi. W pracach tych problematykę porównawczą wypróbowywał na typologii polskiego dramatu (typ pseudoklasyczny i szekspirowski tragedii, Schiller $w$ Polsce). Podał też przykłady badań porównawczych preromantyzmu (Rousseau $w$ Polsce, polski gessneryzm). W Pradze od lat dwudziestych przygotowywał swoje główne dzieła: Polská účast v českém národním obrození (I - 1931, II - 1935, III - 1946). Szczegółowo w nich ukazał rolę polskiej literatury jako bezpośredniej inspiratorki, a jednocześnie pośredniczki wielkich prądów i modeli światowych. Nie tylko przy tym sam przeciwstawiał się niebezpieczeństwu wpływologii, ale i skorygował przesadne poglądy innych o wpływach na czeską literaturę (konkretnie Heidenreicha ocenę wpływu Mickiewicza), pr ze ni kną 1 do właściwego tejże literaturze dynamizmu rozwojowego i usiłował wyjaśniać recepcję jej historycznym zapotrzebowaniem. Wbadaniu roli pośredników podkreślanej przez Van Tieghema w podręczniku z 1931 roku był Szyjkowski rzeczywistym pionierem, kiedy udokumentował rolę pośrednika pełnioną przez cała literaturę ${ }^{18}$.

Gdybyż to potoczna wiedza zechciała się zaznajamiać z pracami naukowymi! Ale w niej królują stereotypy, a takim stereotypem stał się na długie lata Szyjkowski-komparatysta. Po prostu dla folk science to wpływolog, którego nie warto poznawać, a cóż dopiero rzeczowo z nim polemizować. Z czasem „wpływologię” oskarżono o jeszcze większą zbrodnię: ukazując rzekomo wtórność literatur słowiańskich, miała ona skłonić Zachód do wyłączenia ich ze sfery tamtejszych zainteresowań czytelniczych i badawczych ${ }^{19}$.

Ironizując i odrzucając typ refleksji humanistycznej, którą Szyjkowski repre-

18 S. W oll m a n, Česká škola literární komparatistiky. Tradice, problémy, přinos. Praha 1989, s. 48. Podkreśl. K. K.-P.

19 Zob. H. J a n a s z e k - I v a n i č k o vá, Dlaczego literatury słowiańskie sa marginalizowane $w$ międzynarodowym ruchu komparatystycznym? „Mazowieckie Studia Humanistyczne” 13 (2012), nr 1/2, 2012. Autorka powtórzyła tę opinię również w ostatnim wywiadzie udzielonym J. Hviščowi, zamieszczonym w piśmie „Kontakty” (14〈2016〉). Przypomnijmy, że o to samo oskarżała wcześniej 
zentował, nie zastanawiano się też nad jej rozwojem, ewolucją w twórczości naukowej samego Szyjkowskiego. Prawie nikt więc dotąd nie usiłował poddać dokładniejszej analizie tych prac i w ogóle jego działalności polonistycznej w Czechach (która można by określić jako swoista „tragedię humanisty”), nikt nie próbował szczegółowo prześledzić rozwoju myśli uczonego, poddać obserwacji sposobu wchłaniania przezeń nowych tendencji literaturoznawczych oraz wzbogacania poprzez nie własnego warsztatu analitycznego. Jedno stereotypowe, ironicznie i negatywnie wartościujące określenie „wpływolog” kwitowało i deprecjonowało aksjologicznie całożyciowy dorobek zasłużonego autora, odsyłając go na wieki wieków do lamusa historycznoliterackiego ${ }^{20}$.

Oczywiście, zjawisko owo miało swoje przyczyny. Szyjkowski pracując nad problemem polskiego pośrednictwa w odnajdywaniu się literatury czeskiej w kulturze Zachodu nie przeanalizował dostatecznie, jak się wydaje, czym i od jakiego momentu środowisko czeskie różniło się od środowiska polskiego. A były to różnice bardzo istotne dla odbioru zwłaszcza drugiej trylogii uczonego, o roli polskiego romantyzmu w czeskim życiu duchowym, i chodziło tu nie tylko o szczególnie ważne opóźnienie rozwojowe na skutek wyczynów Historii nie sprzyjającej Czechom.

Zacznijmy od przypomnienia faktów: Szyjkowski opracował dwie trylogie, w których starał się ując rolę polskiej literatury w rozwoju nowożytnej literatury czeskiej. Trylogia pierwsza, Polská účast v českém národním obrození, miała wiele recenzji pozytywnych ${ }^{21}$ i długo raczej nie budziła - poza szczegółami - wattpliwości. Kłopoty i wyrzucenie poza nawias współczesnej nauki wywołała natomiast trylogia druga, obejmująca monografie poświęcone trzem polskim wieszczom i ich recepcji w Czechach.

Trylogię tę spotkał szczególnie smutny los. Zaakceptowany do druku w 1949 r. jej tom pierwszy - Adam Mickiewicz $v$ Čechách - przełożony przez znaną tłumaczkę Helenę Teigova, był już w stadium korekty po przełamaniu tekstu ${ }^{22}$, kiedy z druku zrezygnowano, a ręczny skład typograficzny pracy rozrzucono. Jeden egzemplarz

czeski słowianocentryzm M. B obrownicka (Narkotyk mitu. Szkice o świadomości narodowej $i$ kulturowej Stowian zachodnich i południowych. Kraków 2003).

20 Przykładem pewnego lekceważenia może być cytowanie jego pracy bez podania autora, jak to uczynił Słownik terminów literackich M. Głow ińskiego, T. Kostki ewiczowej, A. Okopień-Sławińskiej, J. Sławińskiego (np.: wyd. 2, poszerz. i popr. Wrocław 1988, s.v. Komparatystyka, s. 231) - zwróciła na to uwage M. Skwar a (Polskie serie recepcyjne Walta Whitmana. Kraków 2014, s. 52), która pracę Schiller w Polsce oceniła wysoko.

21 Zob. np. Szyjkowski Marian. Hasło w: Stownik wspótczesnych pisarzy polskich. Red. E. Ko r z en i e w s ka. T. 3. Warszawa 1964. - K. Kr e j čí, recenzja (najważniejsza) w „Pamiętniku Literackim” (1935). Wspomniany słownik podaje, że tomy 4-6, w rękopisie, znajdują się w Archivie Slovanského ústavu w Pradze. Fragment z tomu poświęconego Słowackiemu, zatytułowany „Anhelli” po czesku na tle rozwoju czeskiego kultu Stowackiego, wydrukowano w „Pamiętniku Literackim” w r. 1947 (nadbitka: Warszawa 1948; czeskie tłumaczenie tegoż: Jul. Stowackého „Anhelli” v českých překladech (1872-1919-1946〉. „Slavia” 1947/48); Zob. też M. Szyj kow s ki, O czesko-polskiej wzajemności. Geneza terminu - istota pojęcia. „Sprawozdania z Posiedzeń Towarzystwa Naukowego Warszawskiego". Wydział I. R. 40 (1947). Sporo recenzji powstało również po opublikowaniu przez M. Szyjk ow ski e go Polskiego romantyzmu $w$ czeskim życiu duchowym (Poznań 1947) - zob. Stownik wspótczesnych pisarzy polskich, t. 3, s. 318.

22 Sam Szyjkowski w cytowanym tu już liście do Grabowskiego, pisanym na trzy miesiące przed śmiercią (Bibl. Jagiellońska, Dział Rękopisów), mówi o „szczotkowej odbitce”. 

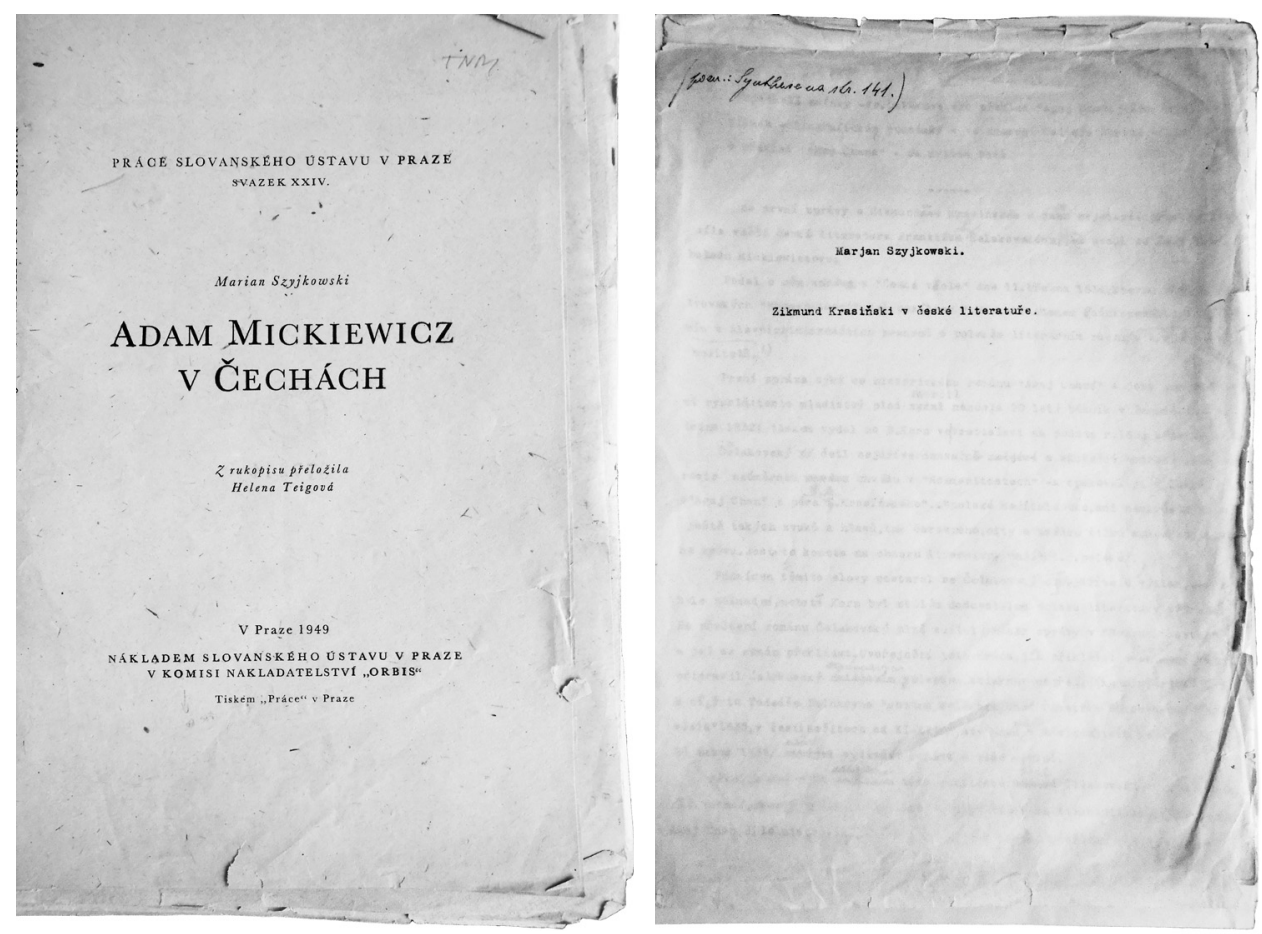

Fot. Roman Baron

owej korekty otrzymał mój mąż, Jarmil Pelikán, jako młody jeszcze pracownik naukowy Uniwersytetu imienia Masaryka, od wdowy po Marianie Szyjkowskim, Katarzyny Szyjkowskiej; dziś znajduje się ów egzemplarz w Dziale Rękopisów Biblioteki Uniwersytetu Łódzkiego. Tom drugi, Julius Słowacki v české literatuře, nie został w Czechach do druku skierowany i chyba zaginął. Kopia maszynopisowa jego polskiej wersji, Juliusz Słowacki w Czechach, którą autor chciał wydać z kolei w Polsce, znajduje się w Bibliotece Zakładu im. Ossolińskich we Wrocławiu, pod sygnaturą 14530/II. Ossolineum, jak twierdzi Szyjkowski w cytowanym tu już liście do Grabowskiego, zakupiło ją od niego. Tom trzeci, Zikmund Krasiński v české literature, też zaginął w Czechach. Istnieje jedynie robocza - również jak poprzednie czeskojęzyczna, ofiarowana Jarmilowi Pelikánowi przez Katarzynę Szyjkowską przebitkowa kopia maszynopisu, z naniesionymi licznymi poprawkami jezykowymi; także ona znajduje się w Bibliotece Uniwersytetu Łódzkiego, któremu przekazałam obie niedrukowane prace Szyjkowskiego przed laty, kiedy miano otworzyć tam bohemistykę ${ }^{23}$.

W języku polskim udało się Szyjkowskiemu opublikować wyłącznie książkę sumująca owe trzy tomy, zatytułowaną Polski romantyzm w czeskim życiu ducho-

23 Istnieje pilna potrzeba zdigitalizowania tej kopii, ponieważ bibułka przebitkowa, na której jest pisana, łatwo ulec może zniszczeniu. Dzięki digitalizacji będzie można udostępnić te prace również Czechom. 
wym (1947). Jest to właściwie esej pozbawiony całego aparatu naukowego. Istnieją jednak na terenie Czech, w języku czeskim, streszczenia wszystkich trzech tomów ${ }^{24}$.

Za najwcześniejszą czeską odpowiedź polemiczną na drugą z wymienionych trylogii Szyjkowskiego (nie przywołująca jednakże jego nazwiska ani bodaj tytułów składających się na nią dzieł, które w kręgach czeskich literaturoznawców musiały być przecież znane choćby $z$ sugerującej treść nazwy czy ze wspomnianych czeskich streszczeń) można by uznać słowa znanego bohemisty Arne Nováka. Wypowiedział je w skróconej wersji swej historii literatury czeskiej, stwierdzając nieco apodyktycznie: „tři největší romantikové polští zủstali právěv Čechách bez trvalejšího ozvuku [trzej najwięksi romantycy polscy akurat w Czechach nie wywołali żadnego bardziej trwałego oddźwięku]"25. Jednak już sama liczba - pojawiających się w pewnych momentach historycznych - tłumaczeń dzieł polskich wieszczów świadczyłaby o czymś innym, a w każdym razie skłaniałaby do postawienia pytania: dlaczego właśnie w Czechach przekładów było tak wiele?26

Novák próbował swoje twierdzenie uzasadnić różnicami występującymi między polską a czeską mentalnością czy tożsamością zbiorową, przyjmując za pisarzami czeskiego odrodzenia narodowego (Ján Kollár, Pavel Josef Šafařik) i późniejszym Janem Máchalem (a może i za Tomášem G. Masarykiem w jego dziele z r. 1919 Evropa a Rusko) czeski stereotyp polskiego tyrteizmu i nielubianego mesjanizmu (,somnia Mickiewiczi”, jak je nazwał Šafařík), dla „ducha czeskiego” ponoć nie do zaakceptowania, bo nie mieszczący się w ówczesnym (a chyba i dzisiejszym) czeskim systemie społecznych identyfikacji pozytywnych. Przytaczam sądy owe w całości:

Czesi i Polacy, mimo pokrewieństwa językowego i mimo bliskiego sąsiedztwa, z którego zresztą w sposób naturalny płyną przejawy życzliwej zgody i powodowane zawiścią próby zaborów terytorialnych, są narodami o bardzo różnych charakterach i kulturach. Nie można tego tłumaczyć ani odmienną strukturą społeczną czeskiej i polskiej zbiorowości, ani tym, że katolicyzm, w Polsce tradycyjny, trwale zachowany i obejmujący wszystkie warstwy społeczeństwa, w Czechach został naruszony racjonalizmem reformacji. Ognista zapalczywość polskiego serca i zawrotna mistyka polskiego ducha są dla Czechów absolutnie obce, co więcej - drażnią ich krytyczne niedowierzanie i trzeźwy s c e p t y c y z m: gorący prąd paroksyzmu, który wionie od Wawelu i Babiej Góry, zatrzymuje się z reguły na paśmie Morawsko-Śląskich Beskidów i tylko może jedyny mistyk Otokar Březina, uczeń Słowackiego, jest tutaj potwierdzającym regułę wyjątkiem. I na odwrót: literatura czeska często się spotyka z polską tam, gdzie chodzi o umocnienie kultury i siły narodu poprzez przeniknięcie rozumem aż ku korzeniom własnej istoty i opisanie tej postawy z realistyczną dokładnością, o czym poglądowo przekonują takie pary pisarzy,

Dwa streszczenia (nazwane przez Szyjkowskiego „syntezami” i zamieszczane pod koniec każdego z niedrukowanych tomów) opublikował sam autor: Adam Mickiewicz v české literatuře. „Slavia” 1939; Julius Stowacki v české literatuře. Jw., 1947, nr 1/2. Streszczenia tomów poświęconych recepcji Mickiewicza i Krasińskiego opublikowałam w periodyku uniwersytetu brneńskiego „Litteraria Humanitas" $(8\langle 2000\rangle)$.

25 A. Novák, Dẽjiny českého písemnictví. Wyd. 2. Praha 1946, s. 17. Za swoistą polemikę z tym $\mathrm{z}$ kolei stanowiskiem można by przyjąć późniejsze wypowiedzi F. W o $11 \mathrm{~m}$ a n a dotyczące słowiańskiej recepcji Mickiewicza oraz inspirowania się kultur słowiańskich kulturą Zachodu poprzez twórczość polskiego poety i jego tejże kultury ocenę - zob. np. studia zamieszczone w książce Slavismy a antislavismy za jara národủ (Praha 1968).

26 Odpowiedź jest zresztą stosunkowo prosta: dlatego, że utwory polskich wieszczów zyskały opinię wielkich dzieł kultury zachodniej, które znać wypada i trzeba. A pracę przekładową ułatwiała przy tym bliskość językowa oraz dość niezła znajomość tragicznych dziejów Polski. 
jak Orzeszkowa - Světlá, Sienkiewicz - Jirásek, Reymont - Nováková. Kiedy tylko wszak duch polski zacznie poszukiwać swych korzeni w podświadomych głębiach mistycznych, Czesi odwracają się od niego z nieprzychylnym niezrozumieniem, dając przed bohaterskim Wyspiańskim pierwszeństwo anarchistycznym mgławicom Przybyszewskiego ${ }^{27}$.

Sądzę, że warto z kolei bliżej przyjrzeć się owym „Beskidom” broniącym Czech przed recepcja polskiego romantyzmu. Wydaje się, że są nimi trzy czeskie bariery recepcyjne, jakie stanęły na drodze badawczej Szyjkowskiego. Oto one: 1) typ odradzającej się kultury, tworzonej przez również odradzające się elity czeskie pochodzenia chłopskiego, plebejskiego i drobnomieszczańskiego; 2) znaczenie czeskiego słowianocentryzmu, bardzo mocno zakodowanego w koncepcji wytwarzanej kultury, oraz podkreślanie słowiańskiej, odrębnej kulturowo europejskości (slovanské evropanstuî, o własnych cechach rozpoznawczych; 3) ergocentryczne, konsekwentnie antygenetyczne nastawienie powstałego i rozwijającego się w Czechach w okresie międzywojennym strukturalizmu, akceptującego myśl immanentnego rozwoju literatury.

Sprawy recepcji literatury polskiej w Czechach wyglądają u Szyjkowskiego dość prosto: dojrzewanie poprzez lekturę, tłumaczenia i krytykę do odbioru zachodnioeuropejskiej literatury wysokiej, $z$ wysunięciem na plan pierwszy literatury polskiej ze względu na sąsiedztwo geograficzne oraz bliskość językową, i następnie pełna, swobodna i twórcza w owej kulturze zachodnioeuropejskiej partycypacja, wzbogacająca dany prąd czy kierunek literacki, jego europejski obraz ogólny. Szyjkowski przy tym dostrzegł dwa momenty szczytowe owego procesu recepcyjnego: w pierwszej trylogii, dotyczącej okresu wcześniejszego, była dlań takim punktem szczytowym twórczość Karela Hynka Máchy ${ }^{28}$, w trylogii drugiej - Jaroslava Vrchlickiego. U pozytywisty, jakim w gruncie rzeczy Szyjkowski pozostał, nie mogło być inaczej: wiara w moc nauki i wiedzy była w nim silnie zakodowana. Przecież o możliwości heterodoksyjnego odbioru ${ }^{29}$ artefaktu nikomu się jeszcze nie śniło! A zwłaszcza w przypadku dwu tak bliskich sobie narodów jak polski i czeski, należących do tego samego, zachodnioeuropejskiego kręgu cywilizacyjnego i posługujaccych się językami, w których wspólne słownictwo osiąga 80\%. Zagadnienie etnocentryzmu i etnorelatywizmu (o etnomasochizmie nikt wówczas nie słyszał), określanie profili identyfikacyjnych grup społecznych i narodowych, wskazywanie na normy, sys-

Novák, op. cit., s. 17-18.

Twórczość tę określił R. J a k obs on (Z zagadnień struktury czeskiego poematu romantycznego. 〈 „Máj” Karla Hynka Máchy〉. „Pamiętnik Literacki” 1960, z. 4) jako - uwaga, uwaga! - „krew z krwi, kość z kości romantyzmu polskiego". Twórczość Máchy, zmarłego w młodym wieku, była faktycznie punktem szczytowym recepcji polskiego romantyzmu przedlistopadowego, bajronicznego (przypomnijmy, że Byrona poznawał on z polskich przekładów, z nich czynił sobie wypiski), stanowiąc jednocześnie próbę naddania jej właściwych dla kultury czeskiej palimpsestów kulturowych. Zob. też mój szkic „Máj” K. H. Máchy wobec polskiej powieści poetyckiej. O rodowodzie genologicznym czeskiego poematu (w zb.: Studia o literaturach i folklorze Stowian. Dedykowane Józefowi Magnuszewskiemu. Warszawa 1991).

Zob. T. Sekigu c hi, Radykalność i otwartość liryki Wislawy Szymborskiej - lektura heterodoksyjna. W zb.: Literatura polska $w$ świecie. Red. R. Cudak. T. 2: W kręgu znawców. Katowice 2007. Zob. też na stronie: http://www.studiapolskie.us.edu.pl/wp-content/uploads/2017/06/T.-2. -W-kręgu-znawców.pdf (data dostępu: 22 III 2018). 
temy wartości oraz zachowania charakterystyczne dla danej grupy i uznawane przez nią jako dobre, prawidłowe i właściwe, śledzenie strategii dialogowych w rozwoju wrażliwości międzykulturowej, istnienie barier recepcyjnych czy zdobywanie nowych kompetencji kulturowych - wszystko to było jeszcze w powijakach, trudno więc czynić Szyjkowskiemu zarzut niedostrzegania czy niewerbalizowania i nieuwzględniania niektórych elementów tej problematyki.

A wracając do czeskich „barier recepcyjnych” - pamiętajmy, że polski profesor przybył do Czechosłowacji w bardzo ciekawym momencie dokonujących się tam przemian kulturowych. Warto może przyjrzeć się im skrótowo po kolei.

Na terenach czeskich w czasie, gdy Szyjkowski tam działał, zaczęto intensywnie rozwijać swoiście „plebejskie” przemiany w literaturze, czyli przyzwalać na wkraczanie do niej nie tylko kultury ludowej, chłopskiej (istniejącej tam, zgodnie z ogólnoeuropejskimi tendencjami romantycznymi, już od początków odrodzenia narodowego), ale i kultury plebejskiej w szerokim tego słowa znaczeniu, kultury marginesów społecznych, legitymizującej „prostactwo”, mającej wiele punktów wspólnych zarówno z oświeceniowym libertynizmem, jak i z dzisiejszym „kampem” avant la lettre, choć koncentrującej uwagę głównie nie na problematyce gender, odmianach preferencji seksualnych, lecz na scaleniu jednorodnych etnicznie i jezzykowo kultur: niskiej i wysokiej, na rozmywaniu czy wręcz burzeniu istniejących pomiędzy nimi barier i blokad recepcyjnych.

Szyjkowski w latach dwudziestych i trzydziestych XX w. znalazł się na samym początku owych zawilych, a $z$ braku perspektywy czasowej - także niezmiernie trudnych wówczas do uchwycenia (a cóż dopiero do ujęcia teoretycznego) procesów ${ }^{30}$. Uczony chyba nie uświadamiał sobie w sposób dostateczny, że w Czechach ma do czynienia z odmiennym systemem semiotycznym, aksjologicznym i estetycznym, przede wszystkim zaś $z$ odmienną imagologia zbiorową i typem kultury, jak też $\mathrm{z}$ odmiennym kodem dyskursu postzależnościowego. $Z$ pewnością nie zdawał sobie również sprawy $\mathrm{z}$ istnienia $\mathrm{w}$ tej kulturze zjawiska, które można by określić

Ostatnio powstało wiele prac polskich bohemistów próbujących uchwycić owe procesy. Przypomnijmy ważniejsze: A. G a wa recka, Margines $i$ centrum. Obecność form kultury popularnej $w$ literaturze czeskiej dwudziestolecia międzywojennego. Poznań 2012. - M. S t e fa ń s ki, Lekcja maszyny. Przypadki poezji czeskiej awangardy. Warszawa 2012. - P. Gi erowski, Struktury historii. O czeskim projekcie dziejów literatury na tle recepcji praskiego strukturalizmu $w$ Polsce. Kraków 2013. - W. S oli ń s ki, Bohumila Hrabala sprawa polska (i inne sprawy). Wrocław 2013. Zob. też prace słowackiego polonisty P. W i n c z e r a: Prenikanie konvencií populárnej literatúry do umeleckej literatúry v próze po druhej svetovej vojnè. „Slovenská literatúra” 25 (1978), nr 6; Literatúra v hladaní čitatela (20. roky: Karel Čapek, Ilja Erenburg). Bratislava 2013. Już wcześniej zaczęły się pojawiać pierwsze analizy czeskie próbujące zaadaptować czeski strukturalizm do badań porównawczych nad strategiami narracyjnymi w literaturze czeskiej i polskiej. Czynił tak na emigracji przede wszystkim - w odniesieniu do Gombrowicza - M. K u n d e r a w swoich esejach dotyczących przemian prozy środkowoeuropejskiej, a w Czechach: P. P o s l e d ní, Hranice dialogu. Česká próza očima polské kritiky. Praha 1998. - J. Holý, Možnosti interpretace. Olomouc 2002 (zwłaszcza w zawartych tam studiach: Dva prokletí a proklinajicí básnici: Witkiewicz, Klíma oraz Proměny utopie a utopie proměn). - J. Tr a v ní č e k, Př́běh je mrtev? Schema a dilemata moderní prózy. Brno 2003. - M. Ajvaz, Př́běh znaků a prázdna. Brno 2006. O niektórych z tych prac informował J. Za re k w artykule O literaturze polskiej $w$ Czechach i jej wspótczesnych czeskich interpretacjach (w zb.: Literatura polska $w$ świecie, t. 3: Obecności $\langle 2010\rangle)$, zupełnie zapominając, w jego części 1, o Szyjkowskim. 
jako przejaw swoistej hybrydyzacji kultury czeskiej oraz kreolizacji czeskiego języka literackiego, a także ich konsekwencji dla zmian w genologii czy ogólnie w poetyce czeskich dzieł literackich.

Tytułem wyjaśnienia dodajmy, że ów proces hybrydyzacji rozpoczął się już w poczatkach XIX w. i zainicjował powstawanie swoistych czeskich gatunków literackich $^{31}$. Kulturę czeską tej doby „budziciele” sytuowali między kulturą wysoką - budowaną wewnątrz kultury niemieckiej, ale w owym właśnie czasie próbująca opuścić zajmowaną dotąd w jej kręgu pozycje „subkultury”, nawet rozpoczynająca wyraźną rywalizację $\mathrm{z}$ dominująca niemiecką kulturą - a czeską kultura „niską, ludową i plebejską, której (co zrozumiałe) domagał się pochodzący z niższych kręgów społecznych jej odbiorca. Drogę dla tej kultury, której kruche zrazu początki widzimy w czeskim odrodzeniu narodowym na progu w. XIX, wytyczano poprzez: 1) tworzenie, jak wspomniano, specyficznie czeskich, z przestrzenia czeskiej kultury związanych gatunków literackich; 2) kreolizację języka, czyli kontaminację języka literatury wysokiej (której rozwój historyczny doznał brutalnego załamania) ze słowem mówionym, $z$ podatnym na nieustanne innowacje jezykiem potocznym, z gwara południowoczeską i slangiem przedmieść; 3) zmiany perspektywy widzenia rzeczywistości: swoisty cywilizm, intymizację codzienności, aż po szczególną Gemütlichkeit - uśmiechnięta życzliwość w traktowaniu świata i ludzi, a więc poprzez humor przechodzacy w ludową groteskę. Inną ścieżką było tworzenie specyficznych strategii narracyjnych czy nowego, również podlegającego przemianom, opowiadacza, bliskiego typologicznie narratorowi polskiej gawędy, choć powstałego w innym kręgu kulturowym i snującego swoje opowieści nie przy dworskim kominku, lecz w karczmie, oberży, gospodzie, przy kuflu piwa... ${ }^{32}$

Tak kształtowana nowoczesna literatura czeska, po okresach dominacji modelu biedermeierowskiego sentymentalizmu czy późniejszego nieco, niekiedy bardzo „idealizującego”, realizmu (gatunek „idylli wiejskiej”), nie tyle otwierała się na tyrteizm i prometeizm polskiego romantyzmu i jego mesjanistyczne pocieszenie po zaznaniu klęski (czerpane $z$ idei pozornie daremnej ofiary, która wszakże miała dać w przyszłości zbawienie-zwycięstwo), ile przyjmowała $z$ akceptacją najnowsze wówczas, płynące $z$ Zachodu (zwłaszcza z Francji) prądy literackie: dadaizm, z jego kultem prymitywizmu, zachwytem dla cielesności, prostactwa nawet, niekształtności, słowem - dla Gombrowiczowskiej „niższości” i „niedojrzałości”, bądź też surrealizm, z jego fascynacją twórczością spontaniczną, grą ze słowem i powstającymi w ten sposób znaczeniami. W wielu momentach odpowiadały one wspomnia-

31 Zob. opracowane przeze mnie w Słowniku rodzajów i gatunków literackich (Red. G. Gazda, S. Ty n e c k a - M a k o w s k a. Kraków 2006) hasła: Arabeska; Báchorka dramatická; Deklamovánka; Hospodská historka; Medailón; Obrana českého jazyka; Ohlas; Proza paraepistolarna; Román-mythus; Román s vlasteneckým tájemstvím; Romanetto; Rozhlásek; Sloupek; Soudnička. Zob. też móją pracę Tożsamość $w$ czeskich gatunkach literackich: narodowa, terytorialna, kulturowa czy historyczna? (,Slavia Occidentalis” nr 73/2 〈2016〉).

32 O sprawach tych pisałam wielokrotnie, np. „Hospodská historka” jako gatunek i tworzywo literackie. "Pamiętnik Słowiański” 1983; Hra na detektivku. W: Š. Vla šín [i in.], Kniha o Čapkovi. Praha 1988; Między mimetyzmem a szyfrem tajemnicy: czeskiego romanetta strategie narracyjne. W zb.: Realizm magiczny. Teoria i realizacje artystyczne. Red. J. Bi ed e r mann, G. Gazda, I. H ü b n e r. Łódź 2007. 
nym tendencjom rozwojowym czeskiej kultury rodzimej, czerpiącej najpierw z ludowości (romantyzm), później z plebejskiego obiegu niskiego.

Powiedzmy też od razu, że Szyjkowski ów niższy obieg uważał za jakąś nie-do-kulturę, którą trzeba dopiero uszlachetnić. Pewne w tym względzie wskazówki daje nam np. jego omówienie dokonanych przez Karela Havlićcka (1821-1856) przekładów ballad humorystycznych Mickiewicza, zwłaszcza Pani Twardowskiej33. Szyjkowski zarzucił tłumaczeniu temu „zatarcie kolorytu szlacheckiego”, wręcz nadanie utworowi - zacytujmy - „czeskiego smaku i czeskiej podmiejskiej atmosfery”, stwierdzając jednoznacznie, że w efekcie czeski tłumacz balladę, „mówiąc szczerze, popsuł", choć czeski z kolei badacz, Emanuel Chalupný, za te właśnie zmiany chwalił Havlička, konstatując, iż ów satyryk swą translację „wypełnił czeskimi ludowymi zwrotami tak dalece, że przekład robi wrażenie jego oryginalnego wiersza" ${ }^{34}$ ). Był to bowiem jeden $z$ pierwszych w kontaktach polsko-czeskich i od razu świetny - przekład z kultury na kulturę. Dziś, po zwrocie translatologicznym, kiedy przyjmujemy, że „wszystko jest przekładem” ${ }^{35}$, wydaje się to rzeczą oczywistą, a umiejętność taka oceniana bywa raczej pozytywnie. Wówczas, jak widać, ten typ tłumaczenia - adaptacji kulturowej wywoływał uczucia co najmniej ambiwalentne, a nawet negatywne jako właśnie rodzaj swoistego zawłaszczenia kulturowego, za główny bowiem obowiązek tłumacza uznawano na ogól „wierność słowu oryginału” 36 , nie dbając już o to, czy owa „wierność” jest rzeczywistym przybliżeniem cudzej twórczości i cudzej rzeczywistości obcemu odbiorcy. A przecież w Czechach doby Szyjkowskiego (i nie tylko w Czechach) pojawiała się już wówczas myśl (Vilém Mathesius), by w toku translacji pamiętać o wrażeniu wywołanym przez oryginał i starać się oddać je w przekładzie. W praktyce jednak dopiero znacznie później zaczęto zastanawiać się nad tym, czy tłumaczenie budzi, przynajmniej ogólnie, w konkretyzacji nowego, w odmiennej kulturze i epoce historycznej wyrosłego odbiorcy, asocjacje podobne do tych, jakie oryginał wywołuje w środowisku rodzimym; jeszcze później - i nieśmiało - zaczęto zastanawiać się nad możliwością prowadzenia lektury kontrastywnej czy odbioru heterodoksyjnego, uwzględniającego różnice kulturowe między oryginałem a obcą konkretyzacją czytelniczą.

Dodajmy, wracając do wątku Pani Twardowskiej, że decyzja tłumacza czeskiego, Havlička, podjęta była świadomie, w swej korespondencji bowiem pisząc o tym przekładzie oświadczał on, iż tworzy „kilka żartobliwych ballad”, i zaznaczał, że pragnie je oddać „w narodowym duchu naszym”37. Havlíček na tej balladzie uczył się, jak prowadzić narrację przyjmując rolę jednego z ludu i przemawiając do lu-

Szyj k ow ski, Polski romantyzm $w$ czeskim życiu duchowym, s. 197. Szerzej o tym przekładzie i opinii Szyjkowskiego piszę w swej książce Karel Havliček-Borouský v kręgu literatury polskiej (Wrocław 1986, s. 43-46).

34 E. Chalu pný, Havliček. Obraz psychologický a sociologický. Praha [1908?], s. 241.

35 Zob. Kultura w stanie przekładu. Translatologia-komparatystyka-transkulturowość. Red. W. B olecki, E. Kraskowska. Warszawa 2012.

36 Było to z kolei reakcją na oświeceniowe adaptacje dalekie od wierności, często pomijające nawet autora oryginału.

37 „Korespodence” Karla Havlička. Vyd. L. Q u i s. Praha 1903, s. 655. 
dowych słuchaczy, zebranych - na co zwrócił uwagę Szyjkowski - „nie w szlacheckiej, lecz w miejsko-proletariackiej" karczmie ${ }^{38}$.

Dziś moglibyśmy powiedzieć, że tu, na naszych oczach, doszło do zamiany polskiej, szlacheckiej narracji oralnej w postaci gawędy - na czeski, plebejski, również oralny gatunek hospodská historka, który pół wieku później zrobił w czeskiej literaturze zawrotną karierę. Cóż by bowiem mówiły czeskiemu odbiorcy będącemu ludowej czy plebejskiej proweniencji, tkwiącemu jeszcze w tejże ludowej czy plebejskiej kulturze, do którego czeski poeta kierował swoją twórczość - cóż by mu mówiły makaronizmy, charakterystyczne dla gawędy szlacheckiej i przez Mickiewicza wiernie utrzymane w funkcji charakterystyki miejsca, czasu i osób? Cóż by im rzekło słowo „kontusz”, w konkretyzacji polskiego odbiorcy niepodzielnie związane $\mathrm{z}$ obrazem szlachcica? Choć słowo to było już w Czechach (marginalnie) znane, szczególnie wśród urzędników narodowości czeskiej, i np. Karel Vladislav Zap tłumaczył je jako „polonezka”39. Czym, jeśli nie pustym dźwiękiem, byłoby porównanie stwierdzające, że Twardowski „podparł się w boki jak basza”, które dla Polaków po wielu wiekach zmagań $z$ butą i nawałą muzułmańską, zakończonych zwycięstwem wiedeńskim, miało swój konkretny koloryt? Natomiast powiedzenie, że Twardowski ,jak probošt si odfukuje" w konkretyzacji czytelnika czeskiego jest idealnym odpowiednikiem zwrotu polskiego, z cała jego, raczej negatywną (otyłość, nadmierna pewność siebie), oceną zawartą w podtekście. I tak by można wymieniać kolejne idiomy, które w swym nagromadzeniu u Havlíčka zmieniły socjolekt narracji i spowodowały przeniesienie utworu z czytelniczego obiegu „elitarnego” do obiegu ludowego, ściślej: plebejskiego. Był to chyba pierwszy w dziejach interakcji kultur czeskiej i polskiej przykład komunikacji międzykulturowej, w której jedna przechodziła w drugą, zachowując atrakcyjność dla czytelnika.

O ile w twórczości dydaktycznej dla ludu takie transpozycje jako rodzaj działalności oświatowej Szyjkowski dopuszczał, o tyle wykluczał je w przypadku literatury wysokiej. Badacz bowiem polską szlachecko-ziemiańsko-inteligencką i wreszcie ogólnonarodową kulturę typu inicjacyjnego (określenie Janusza Lalewicza) przyjmował jako pewien wzór ogólnopolskiej kultury wysokiej i do głowy by mu nie przyszła możliwość jej kontaminacji z kulturą obiegu niskiego, która to kontaminacja dopiero dziś realizuje się $\mathrm{w}$ literaturze polskiej za pośrednictwem poetyki kampu, działania wolnego rynku i nastawionych na ogląalność i poczytność mediów oraz... właśnie literatury czeskiej.

Szyjkowski w ogóle bronił hermeneutyki całości artefaktu, sprzeciwiając się przyjmowaniu w przekładzie jedynie pewnych sensów, zrozumiałych w nowym kontekście kulturowym (przejawiło się to i w jego recenzji, zawierającej negatywną ocenę futurystycznej Hilarowskiej interpretacji Balladyny ${ }^{40}$ ). Dlatego też zmiany tekstu Pani Twardowskiej, wprowadzone przez Havlička świadomie, by stworzyć rodzime, czeskie kulturowe możliwości konotacyjne, denotacyjne i asocjacyjne,

Szyj k ow ski, Polski romantyzm w czeskim życiu duchowym, s. 197.

Mimo to jednak jeszcze J. Hašek w swych opowiadaniach mylił kontusz z chłopską sukmaną, choć znał rzeczywistość polską ze swych wędrówek po Galicji. 
uznał za błąd i „popsucie” Mickiewiczowskiej ballady. Ale cóż: od dzisiejszej refleksji metateoretycznej dzieliło polskiego badacza jeszcze ładnych kilka dziesiątków lat. W czasie powstawania obu trylogii Szyjkowskiego hołdowano dość powszechnie przekonaniom o zakodowanym w utworze znaczeniu kanonicznym, choć od połowy lat trzydziestych XX w. dostępne już były poglądy Romana Ingardena na temat powstawania znaczeń dzieła w odbiorze, czyli w „konkretyzacji” czytelniczej, a od lat czterdziestych stwierdzenia Felixa Vodički o wadze „historycznej normy odbioru”, zmieniającej sensy w czytanym artefakcie słownym.

Różnica druga: inaczej niż na terenach polskich przebiegał też w Czechach dyskurs slawistyczny.

Kolejne więc pytanie rodzi się, gdy zaczynamy rozważać stosunek polskiego profesora do czeskich ujęć relacji Wschód-Zachód i do roli Słowian w tym zderzaniu się dwu typów kultur: czy w pełni pojmował on (mówiąc dzisiejszym językiem opisu) prowadzony przez ówczesnych czeskich badaczy ich dyskurs slawistyczny ${ }^{41}$ ? Dyskurs toczacy się wtedy w Czechach dwukierunkowo: jeden, wcześniejszy nieco, który, jak sam Szyjkowski, podążał żmudną ścieżka pozytywistycznych badań genetycznych (w Czechach reprezentowany np. przez Jana Máchala), i dyskurs drugi, który ożywiał wspomnienie o zapoczątkowanym w odległej przeszłości czeskim kulturowym wariancie staro-cerkiewno-słowiańskim; który w poszukiwaniu eidos kultury słowiańskiej przypominał o zrazu bizantyjskich czy grekobizantyjskich korzeniach kultury czeskiej i nie tylko czeskiej (działalność św. św. Cyryla i Metodego, stworzenie przez nich pisma słowiańskiego i wprowadzenie, po hebrajskim, grece i łacinie, czwartego języka liturgicznego - słowiańskiego). I który stał na stanowisku nie tyle może politycznie zabarwionego - a dla Polaków osławionego i nie do przyjęcia - panslawizmu (rusofilstwo, rusocentryzm i samodzierżawie o wschodnio-azjatyckim pochodzeniu), ile słowianocentryzmu, a więc ukazania „słowiańskiego kontynentu" jako spójnej, dość homogenicznej przestrzeni kulturowej o własnych, dających się wyodrębnić cechach w jej zderzeniu i współżyciu z Zachodem.

A przykładem tej ostatniej postawy może być w Czechach w Dwudziestoleciu międzywojennym Frank Wollman, który w nawiązaniu do metod badawczych fenomenologii usiłował wykryć w całej kulturze słowiańskiej jej cechy oryginalne, istotne (eidos). Dostrzegał je zaś w pewnym szczególnym charakterze słowiańskich gatunków literackich (np. dramat balladyczny), w silnie wybijającym się w ciagu dziejów dążeniu do realizowania w niej zasady teokracji oraz w ścieraniu się w literaturze słowiańskiej dwu tendencji: aspiracji indywidualistycznych i kolektywizmu, a także w idei służebności literatury wobec zbiorowości-narodu, tak wyraźnej w literaturze polskiej, a według Wollmana - tendencji czy wręcz wartości ogólnosłowiańskiej. Pomysły owe badacz czeski przedstawił w swych studiach o Słowackim, Żeromskim, Reymoncie oraz w kompendium Slovesnost Slovanů (1928; wyd. niemieckie: Die Literatur der Slawen, 2003), powtórzył je zaś w 1938 r. w polemicznym wystąpieniu, w którym zawarł formułę odrębnej, słowiańskiej europejskości (.,slovanské evropanstvi”) ${ }^{42}$.

41 O dyskursie slawistycznym w XIX w. zob. D. K u bi k, Słowiańszczyzna wyobrażona. Próba opisu XIX-wiecznego dyskursu slawistycznego. „Pamiętnik Słowiański” 2012, z. 1/2. 
Mówiąc ogólnie: Marian Szyjkowski w tworzonym i uprawianym przez siebie typie komparatystyki zdawał się hołdować romantycznej perspektywie Mickiewiczowskiej, jaka poeta sformułował w wierszu Do Joachima Lelewela: „A tak, gdzie się obrócisz, z każdej wydasz stopy, / Żeś znad Niemna, żeś Polak, mieszkaniec Europy" ${ }^{43}$, i taka perspektywę zadomowienia kulturowego (tyle że bez członu pierwszego, uwypuklającego tak ważna dla romantyzmu polskiego rolę regionu ${ }^{44}$ ) przeniósł na literaturę czeską, badając w niej pogłos polski.

Jasną odpowiedź na czeski słowianocentryzm, owo slovanské evropanství, przyniósł artykuł Szyjkowskiego na temat historii i treści pojęcia wzajemności słowiańskiej, a zwłaszcza czesko-polskiej ${ }^{45}$. Opisując czeskie dylematy dotyczące tego pojęcia oraz ich historyczne przyczyny, badacz stwierdza stanowczo (powtarzając w tym opinie Brücknera, a z czeskiej strony - Máchala):

Słowiańszczyzna nie tworzyła i nie tworzy żadnej kulturalnej całości i jedności, a nadto w dobie czeskiego odrodzenia przedstawia nie tylko pstrą mozaikę różnych elementów Wschodu i Zachodu, ale i bardzo różne kulturalne poziomy ${ }^{46}$.

Autor przypomina też, że w czasach tegoż odrodzenia czeskiego w pierwszej połowie XIX w. pozytywną rolę w „europeizacji”, „modernizacji”, „emancypacji” (charakterystyczne terminy Szyjkowskiego) czeskiego ducha (czytaj: kultury) i czeskiej poezji mogła odegrać i odegrała wyłącznie literatura polska, wspomagając bratnią kulturę w obliczu jej zaciętej wówczas walki o wydobycie się z przygnębiającej sytuacji istnienia jedynie w formie subkultury w obszarze kultury niemieckiej, na co skazało ją uzależnienie polityczne.

I wreszcie różnica trzecia: różnica między metodą badawczą Szyjkowskiego a czeskim nowoczesnym dyskursem kulturowym ${ }^{47}$, stanowczo odrzucającym genetyzm, stojącym na stanowisku immanentnego rozwoju literatury i reprezentującym postawy wyraźnie i zdecydowanie ergocentryczne. Dyskurs ów został wprowa-

covského problému. Bratislava 1927; K methodologii srovnávací slovesnosti slovanské. Brno 1936, s. 40. Szerzej o tych sprawach pisałam w studium $W$ poszukiwaniu istoty (eidos) Stowiańszczyzny, zamieszczonym w mojej książce Pokłosie komparatysty (Brno 2007). Wiele takich myśli odnajdziemy i w powojennych pracach F. W oll m a n a, szczególnie zaś w książce Slavismy a antislavismy za Jára národů (Praha 1968) oraz w artykule „Somnia Mickiewiczii” („Slavia” 1962, s. 218 n.).

A. M i c ki ew i c z, Do Joachima Lelewela. W: Dzieła. Wyd. Narodowe. T. 1. Oprac. W. B or owy, L. Płoszewski. Warszawa 1948, s. 110.

Zob. choćby romans A. Tys zyński e go Amerykanka $w$ Polsce (Petersburg 1837), gdzie po raz pierwszy jest mowa o regionalnych „szkołach poezji polskiej”. M. Szyjk ow ski, O tzw. „wzajemności” czesko-polskiej. (Wspomnienie historyczne). „Ateneum” 1939, $\mathrm{nr} 3$.

Ibidem, s. 353.

47 Oświetlają go w znacznej mierze prowadzone ostatnio w Polsce (a więc kilkadziesiąt lat po Szyjkowskim) badania i ich rezultaty w postaci licznych studiów i książek, np.: K. Bláh ová, České déjepisectuí v dialogu s Evropou (1890-1914). Praha 2009. - P. V. Zi ma, Komparatistika jako dialogická teorie. W zb.: Národní literatura a komparatistika. Ed. D. Tu r e č e k. Brno 2009. - Europejski kanon literacki. Red. nauk. E. W i c h r ow s ka. Warszawa 2012. - G a w a r e c ka, op. cit. - P. J a n o uš ek, Černá kočka aneb Subjekt znalce $v$ myšlení o literatuře a jeho komunikační strategie. Praha 2012. - Kultura $w$ stanie przekładu. - M. Ma ciołek, Tożsamość narodowa Czechów w świetle piśmiennictwa czeskiego do XVIII wieku. Wrocław 2012. - Gi i row ski, op. cit. - S olińs ki, op. cit. - Win c ze r, Literatura v hl'adaní citatela. 
dzony przez czeski strukturalizm, rozwijający się w Praskim Kole Lingwistycznym (z Romanem Jakobsonem, Janem Mukařovskim, Felixem Vodičką i René Wellekiem $^{48}$ na czele), które ukonstytuowało się około r. 1926, a swoje słynne Tezy ogłosiło w 1929 roku. Tezy zawierały inspirowane językoznawstwem samookreślenie metodologiczne Koła. Wyraźnie też zaznaczyło się w nich ukierunkowanie semiologiczne: uznanie dzieła sztuki za wysoko zorganizowany znak. W dziele literackim starano się badać przede wszystkim sposoby osiągania owej wysokiej organizacji.

Na temat tzw. wpływów wypowiedział się expressis verbis Mukařovský w napisanym po francusku artykule $O$ strukturalizmie (1946):

Tradycyjna koncepcja traktuje wpływ jednostronnie, ujmuje jako trwałe przeciwieństwa stronę wywierającą wpływ i stronę mu ulegająca, nie licząc się z tym, że akceptacja wpływu musi być przygotowana przez warunki rodzime, które decydują o jego znaczeniu i kierunku oddziaływania ${ }^{49}$.

Przypomniał też, że zazwyczaj mamy do czynienia $z$ wielością wpływów, więc w badaniach takich należy i ten fakt brać pod uwagę. W przypadku czeskiej literatury zwracał uwagę na konieczność uwzględnienia całego zespołu wpływów: niemieckich, rosyjskich, francuskich, polskich i słowackich. Czy należy słowa te odczytywać jako ocenę dwu trylogii Szyjkowskiego? Nie udało mi się znaleźć dowodu na to, że Szyjkowski znał ów artykuł, ale przypuścić należy, iż takie poglądy nie były dla niego obce ani całkowicie przeciwstawne jego koncepcjom, choć sam wychodził wyraźnie $\mathrm{z}$ praktycznego założenia, że najpierw trzeba przebadać jedną sfere powiązań (w tym wypadku polsko-czeskich), a potem zając się ewentualnie innymi i na tej podstawie snuć wnioski bardziej uogólniające.

Odrzucenie pozytywistycznego genetyzmu przez czeski strukturalizm odwracało uwage od prac Szyjkowskiego, a zmiany polityczne, jakie zaszły w r. 1948, tylko ów proces pogłębiły. W tymże roku Slovanský ústav stracił prawa wydawnicze, czym można tłumaczyć brutalne przerwanie druku poświęconego recepcji Mickiewicza tomu z drugiej trylogii komparatystycznej Szyjkowskiego. Wkrótce po zwycięstwie komunistów $z$ Gottwaldem na czele zakazano też na czas jakiś uprawiania komparatystyki, uznając ją za naukę kapitalistyczną. Na podobnej zasadzie odrzucono zresztą i strukturalizm. Szyjkowski zmarł w praskim szpitalu właśnie w owym czasie, bo w 1952 roku. Wprawdzie po śmierci Stalina i Gottwalda zaczęto pomału wracać do badań porównawczych, ale wydania prac Szyjkowskiego nikt już się nie podjął, bo zmieniły się priorytety. Dopiero w latach osiemdziesiątych XX w. pojawił się znów czeski głos nawiązujący polemicznie do jego pierwszej trylogii komparatystycznej.

Za taka polemiczna wypowiedź, a i to w odniesieniu do wydrukowanej, dostępnej w bibliotekach trylogii pierwszej można by uznać powstałą w końcu w. XX książkę Vladimíra Macury Znamení zrodu (1983; wyd. rozszerzone: 1995). Autor ten zaproponował zupełnie inny „dyskurs Początku” o czeskim odrodzeniu naro-

Zob. I. Po s píš il, M. Zelen k a, René Wellek a meziválečné Československo. (Ke kořenủm strukturálni estetiky). Brno 1996.

49 J. M u ka ř ov s ký, O strukturalizmie. W: Wśród znaków i struktur. Wybór szkiców. Wybór, red., wstęp J. Sławińs ki. Warszawa 1970, s. 39 (przeł. J. Mayen). 
dowym i o prezentowanej przez Szyjkowskiego koncepcji przyjmowania polskich inspiracji literackich jako jednej z zasadniczych, a przynajmniej ważnych cech tegoż odrodzenia, ba, jako czynnika „zdolnego przekształcić odbiorcę” - jak to współcześnie określał twórca estetyki recepcji, Hans Robert Jauss (pamiętamy znamienne słowa Szyjkowskiego o polskiej roli w „europeizacji”, „modernizacji”, „emancypacji” literatury czeskiej). Otóż temu właśnie stanowisku Macura przeciwstawił koncepcję swoistej gry antropologicznej, prowadzonej $z$ austriacką zwierzchnością przez czeskich patriotów, cichych zwolenników odrodzenia kultury i literatury czeskiej; gry, która po kilku dziesiątkach lat dała pozytywne wyniki i która zaczęła nawet przemieniać się w jedynie możliwy w Czechach rodzaj „mesjanizmu literackiego”. Określił go tak i wydobył znowu Macura, który uznał, że jego wyznacznikami są trzy mity: mit o zrodzeniu odnowionego narodu wśród dołów społecznych, mit ukrzyżowania za wielką ideę husytyzmu i mit zmartwychwstania za pośrednictwem mesjaszy-literatów ${ }^{50}$. Jedynym wszakże otwartym odwołaniem się do polskiego badacza w tej - znów dość zawoalowanej - polemice jest obdarzenie przez Macurę w jednej z jego powieści, w Guwernantce, nazwiskiem „Szyjkowski” studenta Polaka, zwolennika walki zbrojnej z obcym najeźdźcą; jest to u tego badacza-semiotyka sygnał ważny, ale nieczytelny dla zwykłych, niefachowych odbiorców. Dodajmy, że głównym bohaterem owego utworu jest František Ladislav Čelakovský, tematem zaś właśnie doba czeskiego odrodzenia narodowego.

Polemiczny charakter książki Macury Znameni zrodu szczególnie wyraźnie widać, gdy jego poglądy zestawimy z poglądami Szyjkowskiego na charakter działalności twórców odrodzenia czeskiego. Szyjkowski reprezentował kulturę polska, w której poczucie polskiej podmiotowości historycznej było bardzo mocno zakodowane, było czymś oczywistym i ono głównie warunkowało owo trwałe zarzewie stałego oporu wobec zaborców, wielokrotnie przechodzące w powstania zbrojne. Czeskie i polskie odpowiedzi na opresyjne doświadczenia historii były całkowicie odmienne. W kulturze polskiej (pod wpływem wcześnie wytworzonych postaw podmiotowych) wybija się na plan pierwszy - użyjmy określenia Zdzisława Najdera dążność do realizacji „wolności od” obcego jarzma, podczas gdy w kulturze czeskiej widoczne są wysiłki, by wykorzystać „wolność do” działań nie drażniących zaborcy, do poczynań dozwolonych, które nie destabilizowałyby przynajmniej własnego rozwoju gospodarczego i społecznego. Kultura polska preferowała śmiałość myśli, odwage i - przede wszystkim - specyficznie pojmowaną odpowiedzialność za zbiorowość: żywe wciąż pragnienie przywrócenia tejże zbiorowości roli decydującego o sobie podmiotu. Być może, domyślać się tu należy również wpływu tradycji katolickiej czy związanego $\mathrm{z}$ nia przesłania pojednawczego i dialogicznego w obliczu konfliktów jednostek oraz zbiorowości, a także uznawanych przez nie wartości ${ }^{51}$. Z tejże tradycji też, jak się wydaje, wynikały postawy odpowiedzialności za wspólnotę narodową. Miały one natomiast ulegać zanikowi w kulturach protestanckich, preferujących odpowiedzialność przede wszystkim jednostki i głównie za życie

50 V. M a c u r a, Czeski świat w XIX wieku oczyma polskiej szlachcianki. W zb.: Czechy i Polska na szlakach ich kulturalnego rozwoju. Red. J. Grell. Kraków 1998.

51 Zob. A. Gaw k ow s ka, Skandal i ekstaza. Nowy Feminizm na tle koncepcji pojednania wedtug Jana Pawła II. Warszawa 2015. 
własne. Stąd rozwój czeskiej pričinlivosti (zapobiegliwości, pilności), stąd i - w pewnym sensie - powstanie określonych rysów charakterologicznych w typie człowieka, który należy do rodzimego, czeskiego drobnomieszczaństwa. Reprezentuje go choćby pan Brouček z cyklu powieści Svatopluka Čecha czy ojciec Kondelík i narzeczony Vejvara $z$ tak zatytułowanej powieści Ignáta Herrmanna. Ale też stąd typ polskiego bohatera romantycznego, zwłaszcza czasów romantyzmu polistopadowego. Polscy bohaterowie romantyczni (a postawy takie utrzymywały się aż do Powstania Warszawskiego 1944 włącznie) swój konflikt ze światem rozwiązywali zupełnie inaczej niż bohaterowie ówczesnej literatury zachodniej: nie biadolili nad nędzą kondycji ludzkiej w ogóle, podporządkowywali sferę osobista - zbiorowości narodowej, waloryzowali dodatnio śmierć w interesie tejże zbiorowości, a negowali jej znaczenie w aspekcie egzystencjalnym, otwierali przed jednostką rodzaj „transcendencji” historycznej, pośmiertnego życia w przyszłych pokoleniach, w narodzie, w ojczyźnie. Wówczas skrystalizował się ów „podmiot aktywny” polskiego romantyzmu, jak to sformułował Edward Kasperski ${ }^{52}$.

Szyjkowski tę polską oczywistość, ten jawny patriotyzm alla polacca zdawał się przenosić na świadomość czeskich „budzicieli” i analogicznych bodźców dopatrywał się też w ich czynie ${ }^{53}$, choć dostrzegał i wyraźną odmienność obranej przez nich drogi. Swoisty odpowiednik polskiego bohatera romantycznego na początku swych badań widział w szaleńczej na pierwszy rzut oka odwadze czeskich „budzicieli”, podejmujących się zadań z pozoru niemożliwych do wykonania. Dlatego twierdził, iż warci sa polskiego orderu stanisławowskiego Sapere Auso - tym, którzy odważyli się być mądrymi.

Macura - semiotyk, entuzjasta Jurija Łotmana i szkoły tartuskiej - stanowisko takie odrzucił. Wprowadził natomiast wspomniane pojęcie gry, która tłumaczyć może także długotrwałe upodobanie Czechów do mistyfikacji ${ }^{54}$. Jednakże wyliczo-

E. Ka s p er s ki, Podmiot romantyczny. Konsekwencje literackie i filozoficzne. W zb.: Romantyzm a Romantismus. Metamorfózy a analogie v moderni polské a české literatuře. Ed. V. F or k ová, K. Cham onikolas. Praha 2008.

53 Patriotyzmu czynnego domagali się od Czechów już wcześniej M i c ki e wi c z (Literatura słowiańska. W: Dzieła, t. 11 (Przeł., oprac. L. Płoszewski. 1953〉, s. 45), E. Chojecki (Czechia i Czechowie przy końcu pierwszej połowy XIX stulecia. T. 1. Berlin 1847, s. 196) i W. Cy bu l s k i (Przeglad literatury słowiańskiej z r. 1842. „Rok 1843 pod względem Oświaty, Przemysłu i Wypadków Czasowych" 1843, t. 3, s. 78-79, 87-88).

54 Wydaje się, że Czesi z początku traktowali wiele poczynań „budzicieli” narodu jako zabawę w mody europejskie lub przynajmniej pragnęli, by tak ich wysiłki zostały odbierane przez władze austriackie - zob. moje szkice: Mistyfikacje literackie jako czeski sposób przekraczania granic opresyjnej rzeczywistości. W zb.: Podzwonne dla granic. Polsko-czeskie linie podziałów i miejsca kontaktów $w$ języku, literaturze i kulturze. Red. J. Lipowski, D. Żygadło-Czopnik. Wrocław 2009 (także wersja poszerzona: O czeskich mistyfikacjach literackich. W: Čechy krásné, Čechy mé... Czeska i polska literatura we wzajemnych interakcjach. Brno 2017); Nie samym śmiechem Czesi żyja, czyli kłopoty z tożsamościa. „Porównania” 17 (2015). W sumie poczynania takie mówiły jasno: nie walka zbrojna, skazana na bardzo niepewną wygraną, nie demonstracja siły, lecz gra z zaborcą, z której zawsze można się było wytłumaczyć. Wiele o sposobach prowadzenia owej gry mówi też studium K. K r e c č e go Polské poustání a „naše dědina” w jego ksiażce Česká literatura a kulturni proudy evropské (Praha 1975), poświęcone wierszowi J. J. La ng e r a České lesy; wiersz ten w zamiarze autorskim pod metafora „ożywczego wiatru ze wschodu” chwalił polskie powstanie 1830 roku. Autor, wzywany następnie na przesłuchania przez czujną policję austriacką, długo 
ny w cytacie ze wstępu do pierwszej trylogii Szyjkowskiego ogrom wykonanej przez „budzicieli” odrodzeniowych pracy jest już efektem najprawdziwszym, nie zabawą czy gra. Bo też czeskie odrodzenie było m.in. upartym i konsekwentnym wykorzystywaniem niektórych europejskich mód literackich jako szansy narodowej. I była w tym także rzeczywista troska o zbiorowość, zupełnie jednak inaczej niż na terenach polskich przejawiana. Troska biorąca pod uwagę możliwość niepowodzenia i konsekwencji $z$ tego płynących, a egzekwowanych $z$ całą brutalnością przez habsburską „Zwierzchność”, jednocześnie zaś próba przewidującego zapobieżenia tym ostatnim; postępowanie jakby w myśl Hipokratesowej zasady: „primum non nocere”, nie szkodzić budzącemu się narodowi, a więc troska o nienaruszenie odnawianej dopiero tkanki narodowej.

Być może, to głos Macury spowodował chęć wydania po 1989 r. poświęconego Mickiewiczowi tomu z drugiej trylogii Szyjkowskiego, który odnaleziono w Instytucie Słowiańskim w Pradze. Informował mnie o tym w rozmowie Slavomír Wollman. Publikacją miał się zająć Jiři Bečka, doświadczony bibliograf, syn Josefa Bečki, również znanego polonisty. Do wydania tej pierwszej części trylogii ani też jej części dalszych jednak ostatecznie nie doszło, z przyczyn mi nieznanych, a rozwijające się ostatnio w Republice Czeskiej rozważania nad genezą czeskiej romantyczności (romantično) pomijają całkowitym milczeniem znakomitego i zasłużonego dla obu kultur badacza polskiego, tak że nazwiska Szyjkowskiego w tekście czy indeksach coraz liczniejszych, poruszających ów temat książek w ogóle nie ma ${ }^{55}$.

Czas więc najwyższy przerwać to dziwne i niesprawiedliwe milczenie otaczajace zasłużonego badacza polsko-czeskich powiązań literackich, czas docenić jego wysiłki naukowe, zwłaszcza teraz, kiedy najnowsze prace pokazują, jak bardzo Szyjkowski zbliżał się pod wieloma względami do badań penetrujących funkcjonowanie tekstu obcego (a także kierunku i prądu literackiego) w literaturze i kulturze narodowej innej zbiorowości. To on przecież zapoczątkował rozważania nad tym, jakie efekty generuje w kulturze i literaturze narodowej tekst obcy. To on unaoczniał ciag zmian chronologicznych w interpretacji konkretnego tekstu w obcej (naprzód polskiej, potem czeskiej) kulturze, pokazywał, jak tłumaczenia i interpretacje owego tekstu podważaja poetykę literatury docelowej, prowadząc w rezultacie do zmian konwencji literackich w niej obowiązujących. To on wreszcie zwracał uwagę na dialogowy charakter tekstu, nie werbalizując jednak tego problemu.

Bez obawy o możliwość popełnienia błędu można więc stwierdzić, że Szyjkow-

musiał wyjaśniać sens utworu, aż z pochwały powstania wiersz stał się rzekomą pochwałą cesarza Franciszka I i jako taki po małych przeróbkach wszedł wreszcie do księgi pamiątkowej ku czci tegoż cesarza. Tu nasuwa się refleksja, iż losy tego wiersza to zupełna odwrotność losów pieśni Boże, coś Polskę...

55 Ostatnio czescy literaturoznawcy zaczynają zgłębiać koncepcje stosunku czeskiej „romantyczności” zwłaszcza do literatury niemieckiej. Zob. Z. H r b a ta, Romantismus a Čechy. Témata a symboly v literárních a kulturních souvislostech. Jinočany 1999. - Z. H rb a ta, M. Pro c házka, Romantismus a romantismy. Pojmy, proudy, kontinenty. Praha 2005. - D. Tu r e č e k [i in.], České literárni romantično. Synopticko-pulzační model kulturního jevu. Brno 2012. Jest rzeczą charakterystyczną, że w tych książkach w ogóle nie pada nazwisko Szyjkowskiego. Czyżby autorzy byli zupełnie nieświadomi jego badań? Czy też bez słowa uznali je za curiosum wpływologiczne, zbyteczne i dziś nieistotne, więc niebyłe? 
ski dostrzegł wiele problemów, które dopiero w latach siedemdziesiatych XX w. zaczęto znów podejmować i rozwijać. $Z$ tego też względu warto by było, powtarzam, jego drugą, nie wydaną dotąd trylogię zdigitalizować, udostępniając ją w ten sposób także Czechom w Internecie, np. w Polskiej Bibliotece Internetowej lub we wspólnym przedsięwzięciu z czeską Biblioteką Słowiańską (Slovanská knihovna v Praze), by badacze czescy $\mathrm{z}$ kolei mogli ją uwzględniać w swych rozważaniach o korzeniach romantyczności w kulturze czeskiej.

ANEKS 1

\section{List Mariana Szyjkowskiego do Tadeusza Stanisława Grabowskiego}

List, dyktowany przez Szyjkowskiego jego przyjacielowi Jaroslavowi Michlowi (mpis, 1 karta zapisana dwustronnie), przechowywany jest w Bibl. Jagiellońskiej (Dział Rękopisów, sygn. Przyb. 463/77); został tam odkryty przez dra Romana B a r o n a, pracownika Instytutu Historii Akademii Nauk Republiki Czeskiej w Pradze (Historický ústav AV ČR v Praze), zajmującego się kontaktami czesko-polskimi, ze szczególnym uwzględnieniem kontaktów kulturalnych.

Zachowano układ graficzny listu, poprawiono interpunkcję, nieliczne błędy piszacego opatrzono wykrzyknikami.

Praha XIX, Tobrucka 6

21. 6.1952

Kochany Panie Tadeuszu,

w dopełnieniu poprzednio posłanego wyliczenia bibliograficznego uważam za właściwe dodać następujące uwagi.

Nie podałem, co dziwne, kilku moich prac, które pojawiły się już po wojnie w „Przeglądzie Zachodnim” (Poznań). Może nie bez znaczenia będzie zwrócić uwagę na prace niewydane, chociaż do druku już dawno przyprawione. Wyliczam tylko najważniejsze:

Dwie monografie, każda przeszło 300 stronic druku. Z tych pierwsza: Mickiewicz $w$ Czechach $^{1}$ - przyjęta przez Slovanský ústav, doczekała się szczotkowej odbitki. Druga - Stowacki $w$ Czechach $^{2}$, ozdobiona bogatym materiałem ilustracyjnym, została nabyta przez wrocławskie Ossolineum, gdzie snem wiecznym spoczywa.

Obszerniejsze studium o Zeyerze posłałem przed rokiem przeszło do Warszawskiego Towarzystwa Naukowego, a monografia Krasiński $w$ Czechach leży od kilku lat w papierach Polskiej Akademii Umiejętności.

W czasie wojny wybudowałem większe 4-tomowe dzieło pod tytułem Lemierz [!] i lutnia. Część tej pracy pod tytułem Fasci znajduje się u kolegi Francića, który kilka ustępów wydrukował w „Dzienniku Polskim”. Byłbym szczęśliwy, kdyby [!] ${ }^{3}$ Pan Kolega zechciał przeglądnąc ten rękopis, który daje pojęcie o całości.

Z 3-go tomu pracy Lemierz [!] i lutnia, nazwanego Italia, wybrałem ustępy odnoszące się do Słowackiego. W ten sposób powstała monografia Słowacki $w$ Italii, która posłałem Poznańskiemu Towarzystwu Przyjaciół Nauk. Stąd drobny ustęp zjawił się w miesięczniku „Życie a Myśl”.

To jest wszystko, co sobie dziś przypominam po 47 latach mojej pisarskiej działalności. Cieszę się, że mogłem u końca życia, zmorzony ciężką chorobą, podzielić się nimi z kimś tak blizkim [!] i życzliwym jak Pan, kochany Panie Tadeuszu. 
Przesyłam uścisk dłoni i ucałowania rąk dla Miłościwej Pani

[Podpis odręczny:] Marian Szyjkowski

PS. List ten został napisany pod moim dyktatem, dzięki uprzejmości przyjaciela, dr. Jaroslava Michla, bo mój stan zdrowia nie pozwala mi nawet na tak niewielki wysiłek, jak pisanie listów.

[Dopisek Michla:]

Wielce Szanowny Panie Profesorze, jesteśmy, wszyscy przyjaciele Pana Prof. Szyjkowskiego, bardzo nieszczęśliwi z jego długiego cierpienia, niemniej jednak pełni nadziei, że stan jego się wkrótce poprawi. Wspominając ostatni pobyt Szanownego Pana Profesora w Pradze, łączę wyrazy głębokiego szacunku.

\section{Jaroslav Michl ${ }^{4}$}

[Z lewej strony dopisek ręką Szyjkowskiego, sygnowany jego inicjałami:] odp. dn. 30/VI $52^{5}$ SM.

1 Szyjkowski podaje tytuł po polsku, a może tak to zapisał Michl; tytuł czeski brzmi prawie identycznie: Adam Mickiewicz v Čechách.

2 Pełny tytuł: Juliusz Stowacki $w$ Czechach.

3 Forma „kdyby” to bohemizm zapisującego.

4 Nad nazwiskiem - podpis odręczny.

5 Data wskazuje dzień, w którym przyszła odpowiedź na ten list.

\section{ANEKS 2}

\section{Bibliografia ważniejszych prac komparatystycznych Mariana Szyjkowskiego}

Polska jako obszar transferowania zachodnich inspiracji w preromantycznej fazie dziejów literatury polskiej

1912 - Osjan w Polsce na tle genezy romantycznego ruchu. Kraków.

1913 - Myśl Jana Jakuba Rousseaua w Polsce XVIII wieku. Kraków.

1914 - Gessneryzm w poezji polskiej. Kraków.

1915 - Schiller $w$ Polsce. Studium historyczno-porównawcze. Kraków.

1916 - Edwarda Younga „Myśli nocne” w poezji polskiej. (Ze studiów nad geneza polskiego romantyzmu). Kraków.

1920 - Dzieje nowożytnej tragedii polskiej - typ pseudoklasyczny. Kraków.

1923 - Dzieje nowożytnej tragedii polskiej - typ szekspirowski. Kraków.

Polska jako obszar transferujący własne osiagnięcia na polu

literackim na przyjmujacy je czeski obszar transferowania

1931 - Polská účast v českém národním obrození. Cz. 1. Praha.

1934 - Polská účast v českém národním obrození. Cz. 2. Z rukopisu přel. V. Kredba. Praha.

1946 - Polská účast v českém národním obrození. Cz. 3. Z rukopisu přel. J. V. Bečka. Praha.

1934 - Przedmowa. W: K. Krejčí, Polská literatura ve vírech revoluce. Praha.

1935 - Kazimierz Brodziński $w$ Czechach. (Z cyklu „Polskie peregrynacje do Pragi i Karlowych Warów”). „Slavia Occidentalis”. T. 14. 
1935 - Mickiewicz jedzie do Pragi. (Z cyklu „Polskie peregrynacje do Pragi i Karlowych Warów”). „Pamiętnik Literacki”.

1935 - Polski udział $w$ czeskim odrodzeniu. (Próba rekapitulacji). Poznań 1935.

1935 - Wileńscy filomaci $w$ Pradze. (Z cyklu „Polskie peregrynacje do Pragi i Karlowych Warów”). „Pamiętnik Literacki”.

1936 - Ignacy Krasicki $w$ czeskim odrodzeniu. „Pamiętnik Literacki”.

1936 - Polskie peregrynacje do Pragi i Karlowych Warów. Od Augusta Mocnego do Adama Mickiewicza. Bydgoszcz 1936.

1939 - O tzw. „wzajemności” czesko-polskiej. (Wspomnienie historyczne). „Ateneum”, nr 3, s. 351-363.

1947 - Jul. Słowackého „Anhelli” v českých překladech (1872-1919-1946). „Slavia” $1947 / 48$, z. 3/4.

1947 - Polski romantyzm $w$ czeskim życiu duchowym. Poznań.

1948 - Czeskie odrodzenie w XIX wieku. Łódź.

1948 - Karol Hynek Mácha, twórca czeskiego romantyzmu. Warszawa.

1955 - Stanisław Przybyszewski w Czechach. Podał do druku K. Krejčí. W zb.: Česko-polský sborník vědeckých prací. Red. M. Kudělka. T. 2. Praha.

Ine dita

Adam Mickiewicz v Čechách. Přel. H. Teigová. Praha 1949 (luźne kartki, korekta po przełamaniu tekstu, druk przerwany, skład rozrzucony; tekst w posiadaniu Bibl. Uniwersytetu Łódzkiego).

Zikmund Krasiński $v$ české literature (przebitka maszynopisowa, w posiadaniu Bibl. Uniwersytetu Łódzkiego).

Juliusz Stowacki $w$ Czechach (kopia maszynopisowa wersji polskiej znajduje się w Bibl. Zakładu im. Ossolińskich we Wrocławiu, pod sygnatura 14530/II).

Lemiesz i lutnia. T. 1: Wspomnienia. Muzeum Literatury im. Adama Mickiewicza w Warszawie, mpis nr 1382.

Czeskie streszczenia drugiej, nie wydanej trylogii, nazywane przez Szyjkowskiego „syntezami”

Adam Mickiewicz v české literární tvorbě. „Slavia” 1939. Opublikowane przez autora. Julius Stowacki v české literature. „Slavia” 1947/48, nr 1/2. Opublikowane przez autora.

Zikmund Krasiński v české literatuře. „Litteraria Humanitas” 8 (2000). Opublikowane przez K. K.-P.

\author{
Abstract \\ KRYSTYNA KARDYNI-PELIKÁNOVÁ Masaryk University, Brno
}

MARIAN SZYJKOWSKI'S COMPARATIVE STUDIES

The author of the paper sketches a profile of a Polish comparative studies professor, emphasising the period of his creativity in the Czech Republic as a researcher of Polish-Czech literary relationship and reception of Polish literature in the Czech Republic. She also tries to explain Szyjkowski's opus magnum reception history, the first part of which (Polská účast $v$ českém národním obrození 〈Polish Participation in the Czech National Revival , vol. 1-3) met with positive reception, while the second trilogy, referring to the former and concerning the role of the Polish Romanticism in the Czech spiritual life (Adam Mickiewicz $v$ Čechách 〈Adam Mickiewicz in the Czech Republic〉, Zikmund Krasiński v české literature 〈Zygmunt Krasiński in Czech Literature〉, and Juliusz Stowacki w Czechach 〈Juliusz Stowacki in the Czech Republic)) still remains typewritten and is presumably unknown since it is unmentioned by the contemporary Czech romanticity (romantično) researchers. 